\title{
Comparative Study on Lipase Immobilized onto Organo- Cation Exchanged Kaolin and Metakaolin: Surface Properties and Catalytic Activity
}

\author{
Hana Meftah Elgubbi, Siti Salhah Othman*), Farah Wahida Harun \\ Faculty of Science \& Technology, Universiti Sains Islam Malaysia, Bandar Baru Nilai, 71800 Nilai, \\ Negeri Sembilan, Malaysia.
}

Received: 30th January 2021; Revised: 30th March 2021; Accepted: $1^{\text {st }}$ April 2021

Available online: $6^{\text {th }}$ April 2021; Published regularly: June 2021

\section{Abstract}

Clay mineral has received much attention to be used as biocatalysts as it is cheaper, easily available and environmentally friendly. However, the use of unmodified clay, in particular kaolin for enzyme immobilization showed unsuitability of this support due to its negative charge. In this study, the hydrophobic properties of kaolin and metakaolin (kaolin heated to $650{ }^{\circ} \mathrm{C}$ ) were adjusted by the intercalation with benzyltriethylammonium chloride (BTEA-Cl), at concentrations 2.0 times the cation exchange capacities (CEC) of the clays. The supports were then used for immobilization of lipase from Candida rugosa (CRL). From the study, the highest percentage of lipase immobilization was achieved (70.14\%), when organo-modified metakaolin (2.0 MK) was used. The supports as well as the immobilized biocatalysts were then characterized by X-ray diffraction, Fourier transform infrared spectroscopy, scanning electron microscopy, and nitrogen adsorption techniques. Comparisons of the efficiencies of immobilized with free CRL in the synthesis of nonyl hexanoate showed that immobilized CRL achieved enzymatic activities of between $5.24 \times 10^{-3}$ to $3.63 \times 10^{-3} \mathrm{mmol} / \mathrm{min} / \mathrm{mg}$, while free CRL achieved enzymatic activity of $3.27 \times 10^{-3}$ $\mathrm{mmol} / \mathrm{min} / \mathrm{mg}$ after $5 \mathrm{~h}$ of reaction at $30{ }^{\circ} \mathrm{C}$. The immobilized CRLs also maintained $70.81 \%-80.59 \%$ thermostabilities at $70{ }^{\circ} \mathrm{C}$ as compared to the free CRL (28.13\%). CRL immobilized on $2.0 \mathrm{NK}$ and $2.0 \mathrm{MK}$ also maintained $38.54 \%$ and $62.56 \%$, respectively, of the initial activities after 10 continuous cycles, showing the excellent stability and reusability of the immobilized lipases, suitable as substitute for expensive, hazardous catalysts used in industries.

Copyright (C) 2021 by Authors, Published by BCREC Group. This is an open access article under the CC BY-SA License (https://creativecommons.org/licenses/by-sa/4.0).

Keywords: Kaolin; Metakaolin; Organo-modification; Candida rugosa lipase; Immobilization

How to Cite: H.M. Elgubbi, S.S. Othman, F.W. Harun (2021). Comparative Study on Lipases Immobilized onto Organo-Cation Exchanged Kaolin and Metakaolin: Surface Properties and Catalytic Activities. Bulletin of Chemical Reaction Engineering \& Catalysis, 16(2), 214-233 (doi:10.9767/bcrec.16.2.10230.214-233)

Permalink/DOI: https://doi.org/10.9767/bcrec.16.2.10230.214-233

\section{Introduction}

Lipase from Candida rugosa (CRL) is a wellknown microbial lipase, able to hydrolyze synthetic or natural triacylglycerol and esterify them in organic medium [1-2]. Reactions which

\footnotetext{
* Corresponding Author.

Email: salhah@usim.edu.my (S.S. Othman);

Telp: +606 798 8000, Fax: +606-798 6566
}

include CRL is more environmentally affable since enzymatic catalysis is more similar to the natural metabolic pathways as compared to most chemical reactions [3]. Most chemically catalyzed esterification reactions are hazardous due to the use of mineral acids such as sulphuric acid or hydrofluoric acid as homogeneous acid catalysts, which usually leads to pollution and corrosion issues [4]. The enzymatic synthe- 
sis of esters has attracted much attention not just because of its eco-friendly synthesis, but also due to the intrinsic catalytic selectivity of enzymes, efficiency of the synthesis and high purity of the esters produced. In addition, the enzyme-catalyzed reactions can be carried out at ambient conditions, suitable for use with advanced equipment which requires engineered enzymatic properties as important requirement by industrial manufacturers [5-6].

In spite of the benefits mentioned above, the limitations of enzyme applications are fundamentally owing to the high cost of the operations involving enzymes in liquid form. This is due to the non-reusability and difficulty encountered to separate the enzymes from the reaction or to isolate products from the reaction [7].

To overcome these problems, enzymes have been immobilized on solid supports to allow enzyme recyclability and ease enzyme separation from the reactants. Solid supports used for enzyme immobilization protect the structure of the enzyme, leading to enhanced stability even in the presence of organic solvents and when used in extreme $\mathrm{pH}$ or temperatures [8-11]. From the variety of immobilization methods, enzyme adsorption is still the most straightforward one. This method is also cost-effective, able to retain the natural enzymatic structure and properties, and causes less disruption on enzyme structure and properties compared to immobilization via chemical modifications (e.g. covalent bonding and cross-linking) [12-14].

Among the various materials used as supports for immobilization of CRL by physical adsorption are hydrophobic resins [15], chitosan [16], Maghnite clay [17], and modified graphene oxide nanosheets [18]. However, some of the materials used as support for immobilization are synthetic, with low mechanical strength and expensive which may not suite the demands and requirements for industrial applications. From an economic point of view, kaolin, a clay mineral that can be found abundantly in nature, chemically inert and nontoxic, offers greater potential for use as support for enzyme immobilization. Furthermore, it is mechanically strong, resistant towards microbes, and thermally stable, for use in reactors [19-20]. However, the absorbency of natural kaolin clay is still considerably low when compared to other absorbent materials. Musa et al. [6] have compared the use of chitosan, amberlite, celite and kaolin in the immobilization of lipase from Antarctic Pseudomonas AMS8. Re- sults showed that kaolin possesses lowest adsorption capacity towards AMS8 lipase and exhibited lowest ester conversion (40.4\% and $41 \%$ in free solvent and toluene) as compared to other supports studied in the esterification of ethyl hexanoate. These results were due to electrostatic forces and negative charge on kaolin, unsuitable for enzymes such as porcine pancreatic lipase and acid phosphatase [2123].

Hence, further modification of kaolin clay has to be carried out to ensure that the support is positively charged and suitable for lipase immobilization. In an attempt to modify kaolin clay, appropriate heat treatment within a temperature range of 650 to $800{ }^{\circ} \mathrm{C}$ is often used, which leads to break down of the kaolinite structural layers containing alumina and silica to become amorphous. At this stage, metakaolin which is more suitable for use as immobilization support will be formed [19,24,25].

As compared to other enzymes, lipase possesses more hydrophobicity. Thus, the use of hydrophobic support is important to ensure lipase changes its conformation from closed-form to an open one, where catalytic activity will be enhanced [26]. In this study, kaolin and metakaolin clays were modified using organic cations $\left(\mathrm{BTEA}^{+}\right)$with reference to their cation exchange capacities.

The focus of the present work is to compare abilities of free CRL with CRL immobilized onto organo-modified kaolin and metakaolin in the synthesis of nonyl hexanoate, a common flavouring component [28] and a constituent of the Mediterranean flowering plant, hartwort (Tordylium L.) species [29].

\section{Materials and Methods}

\subsection{Materials}

The kaolin clay was collected from Perak, Malaysia. The surfactant used in this study, benzyltriethylammonium chloride $(\geq 98 \%)$ was purchased from Merck, Germany. Proteins, $C$. rugosa lipase, Type VII, $\geq 700$ unit/mg solid (EC 3.1.1.3) and bovine serum albumin ( $\geq 98 \%$ ) were purchased from Sigma-Aldrich, St. Louis, USA. Nonanol (97\%), and hexanoic acid ( $\geq 98 \%)$ were purchased from Merck, Germany, while hexane (95\%) was purchased from SigmaAldrich, St. Louis, USA. Other chemicals, solvents and reagents used in this study were of analytical grade. Deionized water was utilized in the preparation of aqueous solutions. 


\subsection{Preparation of Supports}

\subsubsection{Preparation of kaolin}

The kaolin clay which was previously received in flaky form was grounded and sieved using analytical sieve shaker (AS200, Retsch, Germany) to obtain 100 mesh of particles. The kaolin was heated at $120{ }^{\circ} \mathrm{C}$ for $5 \mathrm{~h}$. After heating, the clay was cooled and analysed using energy dispersive X-ray (EDX) spectroscopy technique.

\subsubsection{Preparation of metakaolin}

The kaolin clay which was prepared in Section 2.2.1 was thermally treated in a laboratory programmable furnace (BWF 1100 Carbolite, England) at a constant rate of $10{ }^{\circ} \mathrm{C} / \mathrm{min}$ for $5 \mathrm{~h}$ at $650{ }^{\circ} \mathrm{C}$. After cooling, the resultant metakaolin clay was sieved and analysed using energy dispersive X-ray (EDX) spectroscopy technique.

\subsubsection{Determination of cation exchange capaci-} ty

The clay (6 g) was homoionized with 300 $\mathrm{mL}, 1.0 \mathrm{M} \mathrm{NaCl}$ for $24 \mathrm{~h}$. The clay was then filtered and rinsed several times with deionized water until free of chloride (tested by using 0.1 $\mathrm{M}$ silver nitrate solution). The resultant clay was dried, before its cation exchange capacity (CEC) was determined by Santamarina et al. using methylene blue method [30]. The CEC was calculated based on the volume of methylene blue added to the clay dispersion, until the saturation point was achieved using the following formula:

$$
C E C=\frac{E \times V}{W} \times 100
$$

Whereby; $C E C$ is cation exchange capacity in meq/100 $\mathrm{g}$ of clay, $E$ is milliequivalents of methylene blue per $\mathrm{mL}, V$ is volume (in $\mathrm{mL}$ ) of methylene blue solution required for the titration, and $W$ is weight (in g) of dry clay.

\subsubsection{Modification of clays with organo surfac-} tant

Modification of kaolin (NK) and metakaolin (N-MK) was performed by using benzyltriethylammonium chloride (BTEA-Cl) at concentrations 2.0 times the CEC of the clays. To produce kaolin modified with $\mathrm{BTEA}^{+}$at concentration 2.0 times the CEC of the clay (2.0 NK), 20 $\mathrm{g}$ of NK was added to $200 \mathrm{~mL}$ of deionized water containing $0.228 \mathrm{~g}$ of BTEA-Cl. On the other hand, to produce metakaolin modified with
$\mathrm{BTEA}^{+}$at concentration 2.0 times the CEC of the clay (2.0 MK), $20 \mathrm{~g}$ of N-MK was added to $200 \mathrm{~mL}$ of deionized water containing $0.137 \mathrm{~g}$ of BTEA-Cl. This was followed by stirring the dispersions at $250 \mathrm{rpm}$ overnight and heating to $45{ }^{\circ} \mathrm{C}$ for $10 \mathrm{~h}$. The suspension was then centrifuged at $3000 \mathrm{rpm}$ for $30 \mathrm{~min}$ before the solid collected was washed several times with deionized water and dried at $35{ }^{\circ} \mathrm{C}$ for $12 \mathrm{~h}$.

\subsection{Immobilization of Lipase}

Crude lipase from C. rugosa ( $1.5 \mathrm{~g})$ was dispersed in distilled water $(15 \mathrm{~mL})$. The mixture was stirred for $30 \mathrm{~min}$, then centrifuged at $10,000 \mathrm{rpm}$ for $15 \mathrm{~min}$ at $0{ }^{\circ} \mathrm{C}$. The supernatant collected was used as partially purified lipase. The immobilization of lipase was carried out by dispersing $2.0 \mathrm{~g}$ of the support in $15.0 \mathrm{~mL}$ of lipase supernatant at room temperature with continuous agitation in water bath shaker (Model 903, Protech, Malaysia) at $100 \mathrm{rpm}$ for $1 \mathrm{~h}$. The lipase-loaded support was then filtered using Whatman no. 1 filter paper and lyophilized in a freeze drier (FD-550, Eyela, Japan).

\subsection{Protein Assay}

The amount of protein was determined based on the Bradford [31] method using bovine serum albumin (BSA) as standard protein. The protein loading capacity of the support, expressed as amount of protein $(\mathrm{mg})$ per gram of the support, was determined using Equation (2).

Protein loading capacity of the support $(m g$ protein $/ g$ support $)=\frac{A-B}{W}$

Where $A$ is concentration of protein in supernatant prior to immobilization $(\mathrm{mg} / \mathrm{mL}) ; B$ is concentration of protein in supernatant after immobilization $(\mathrm{mg} / \mathrm{mL})$, and $W$ is the weight of support for immobilization (g). The percentage protein immobilized was calculated using Equation (3).

Immobilization $(\%)=\frac{A-B}{A} \times 100 \%$

2.5 Characterization of Supports and Immobilized Lipases

The supports and the immobilized lipases were analysed using $\mathrm{Cu}$ X-ray diffractometer (D8 Advance, Bruker AXS, Germany) in Cu X ray tube at $40 \mathrm{kV}$ and $40 \mathrm{~mA}$ operating conditions. The samples were individually placed on sample holders followed by insertion into the 
sample chamber and subjected to analysis from $10^{\circ}$ to $80^{\circ}$ for $2 \theta$ at room temperature with a scan rate of $2 \theta$ per min. The X-ray diffraction was recorded using DIFFRAC Plus software for data acquisition and analysis.

In the analysis using Fourier transform infrared (FTIR) spectrometer, samples were prepared employing the $\mathrm{KBr}$ pellet technique. The spectra were recorded with the range of 500$4000 \mathrm{~cm}^{-1}$ using Perkin Elmer, USA (Spectrum 400, USA) FTIR spectrometer. Samples were also analysed using Hitachi, Japan (S-3400N) scanning electron microscope (SEM). Prior to analysis, samples were sputter coated with a thin film of gold prior to imaging. The analysis of surface area and porosity of the samples were done using Micromeritics (ASAP 2020) surface area and porosity analyser following the Brunauer-Emmet-Teller (BET) method. Analysis was performed at $77 \mathrm{~K}$, where samples were initially outgassed at $30{ }^{\circ} \mathrm{C}$ for $1 \mathrm{~h}$ and further outgassed at $8 \mathrm{~h}$ at $40{ }^{\circ} \mathrm{C}$ in vacuum, prior to nitrogen adsorption using the instrument.

\subsection{Enzymatic Esterification Assay}

The enzymatic esterification reaction comprised of equal molar $(2.0 \mathrm{mmol})$ of hexanoic acid and nonanol $(2.0 \mathrm{mmol})$ and $0.05 \mathrm{~g}$ of free CRL containing $1.76 \mathrm{mg}$ protein, in $2.0 \mathrm{~mL}$ of hexane. Amounts of immobilized CRL were adjusted to suite the amount of protein as in the free CRL, in enzymatic esterification assay involving immobilized CRL. Assay were conducted in triplicates together with control (reaction without enzyme). All reactions were subjected to incubation at $30{ }^{\circ} \mathrm{C}$ for $5 \mathrm{~h}$, with continuous shaking at $150 \mathrm{rpm}$ in a horizontal water bath shaker (Model 903, Protech, Malaysia). The reactions were then terminated by the addition of $10 \mathrm{~mL}$ of ethanol/acetone $(1: 1, \mathrm{v} / \mathrm{v})$ and the remaining free fatty acid in the reaction mixtures were titrated with $0.15 \mathrm{M} \mathrm{NaOH}$, using phenolphthalein as indicator. The enzyme specific activity was expressed as $\mathrm{mmol}$ ester/min/mg of protein determined using the following Equation (4):

Specific activity $(\mathrm{mmol} / \mathrm{min} . \mathrm{mg})=\frac{[(\mathrm{Va}-\mathrm{Vb}) \times M]}{W \times t}$

From the data obtained, percentage of ester converted based on the amount of hexanoic acid consumed was calculated using Equation (5).

$$
\text { Conversion of ester }(\%)=\frac{V a-V b}{V a} \times 100
$$

In these equations, $V a$ is the titration volume of $\mathrm{NaOH}$ for control $(\mathrm{mL}), V b$ is the titration volume of $\mathrm{NaOH}$ for sample (mL), $M$ is molarity of $\mathrm{NaOH}, t$ is the reaction time (min) and $W$ is the amount of protein involved in the reaction (mg).

\subsection{Thermal Stability Assay}

Free and immobilized CRL were subjected to pre-incubation at different temperatures (30, $40,50,60$ and $70{ }^{\circ} \mathrm{C}$ ) for $1 \mathrm{~h}$ in sealed vials before they were allowed to cool at room temperature prior to enzymatic esterification assay. The specific activity of the immobilized CRL and the percentage of ester conversion were determined using Equations (4) and (5). The relative activities of the enzymes were calculated in relation to the optimum specific activity, as shown in Equation (6).

Relative Activity $=\frac{\text { Specific activity at specific condition }}{\text { Specific activity at optimum condition }} \times 100$

\subsection{Immobilized Lipase Reusability Assay}

Reusability of the immobilized CRL were assayed following the enzymatic esterification assay which were repeated for 10 consecutive cycles. After each cycle, the immobilized CRL was collected, washed and used in the next cycle, while the reaction mixture was carefully drained and the remaining fatty acid was analysed following methods in Section 2.6. The specific activity of the immobilized CRL and the percentage of ester conversion were determined using Equations (4) and (5).

\section{Results and Discussion}

3.1 Characterization of Kaolin and Metakaolin Using Energy Dispersive X-ray Spectroscopy Technique

The elemental compositions for kaolin and metakaolin obtained from energy dispersive Xray (EDX) spectroscopy are shown in Table 1.

Table 1. Chemical compositions of kaolin and metakaolin samples.

\begin{tabular}{cccc}
\hline \multirow{2}{*}{ Element } & \multirow{2}{*}{ Compound } & \multicolumn{2}{c}{ Compositions (\%) } \\
\cline { 3 - 4 } & & Kaolin & Metakaolin \\
\hline $\mathrm{C}$ & $\mathrm{C}$ & 24.75 & - \\
$\mathrm{Al}$ & $\mathrm{Al}_{2} \mathrm{O}_{3}$ & 36.12 & 44.83 \\
$\mathrm{Si}$ & $\mathrm{SiO}_{2}$ & 36.04 & 50.79 \\
$\mathrm{~K}$ & $\mathrm{~K}_{2} \mathrm{O}$ & 1.68 & 2.44 \\
$\mathrm{Fe}$ & $\mathrm{Fe}_{2} \mathrm{O}_{3}$ & 1.41 & 1.94 \\
\hline \multicolumn{2}{c}{ Total } & 100 & 100 \\
\hline
\end{tabular}


The results shown were as obtained in the analysis using EDX. It reveals the presence of silica and alumina as major constituents in the samples along with traces of potassium and iron oxides. The $\mathrm{SiO}_{2}$ and $\mathrm{Al}_{2} \mathrm{O}_{3}$ were $72.16 \%$ of the total components of kaolin and $95.62 \%$ of the total components of metakaolin.

The increased percentage of $\mathrm{Al}_{2} \mathrm{O}_{3}$ and $\mathrm{SiO}_{2}$ from $36.12 \%$ and $36.04 \%$, respectively for kaolin to $44.83 \%$ and $50.79 \%$, respectively for metakaolin is in agreement with the idea that thermally-treated kaolin (metakaolin) should contain $40 \%$ to $45 \%$ of $\mathrm{Al}_{2} \mathrm{O}_{3}$ and $50 \%$ to $55 \%$ $\mathrm{SiO}_{2}$, as reported by Ramli and Alonge [32]. Thermal treatment or calcination at high temperatures results in the structural breakdown of kaolin causing the $\mathrm{OH}$ groups in the kaolin structure to disappear, thus allowing the $\mathrm{Al}$ and $\mathrm{Si}$ atoms in the structure to realign. This has resulted in the realignment of the $\mathrm{Al}-\mathrm{O}$ network structure, while the $\mathrm{Si}-\mathrm{O}$ network remained unchanged with the appearance of penta- and tetra-coordinated structure [33].

Other oxide compounds found in the samples were $\mathrm{Fe}_{2} \mathrm{O}_{3}$ and $\mathrm{K}_{2} \mathrm{O}$. Despite being present in small percentages, the variance in the compounds indicated the impact of the thermal treatment on the kaolin clay. EDX mappings which indicated $\mathrm{Si}, \mathrm{Al}, \mathrm{K}, \mathrm{O}$, and $\mathrm{Fe}$ elemental compositions on selected areas for kaolin and metakaolin are as shown in Figures 1 and 2.

\subsection{Determination of Cation Exchange Capaci- ty (CEC)}

In the determination of cation exchange capacity (CEC), the NK exhibits a CEC of 2.5

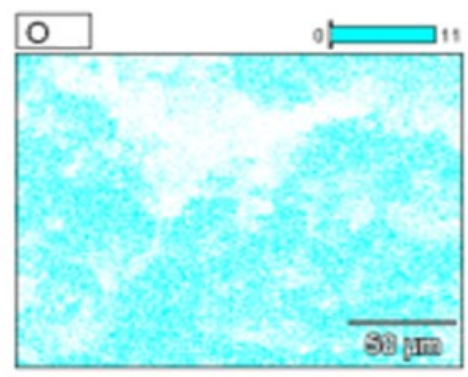

Oxygen

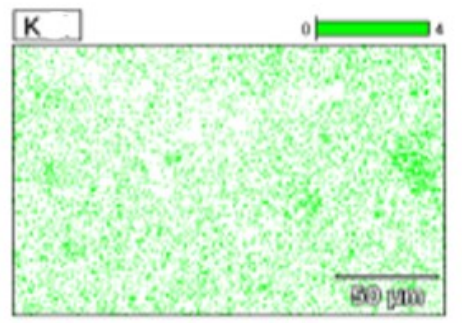

Potassium

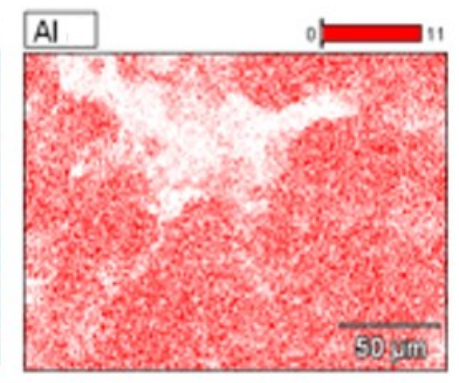

Aluminum

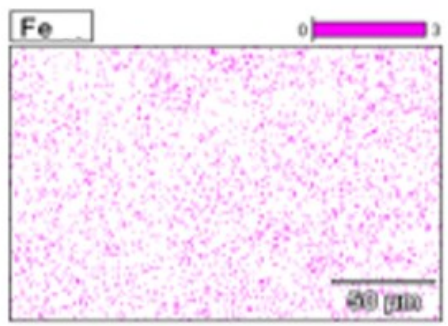

Iron

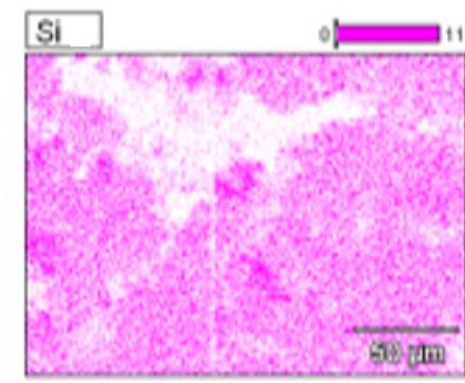

Silicon

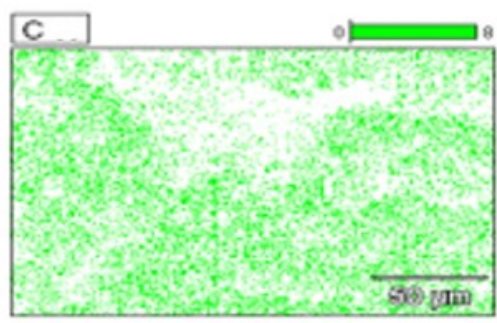

Carbon

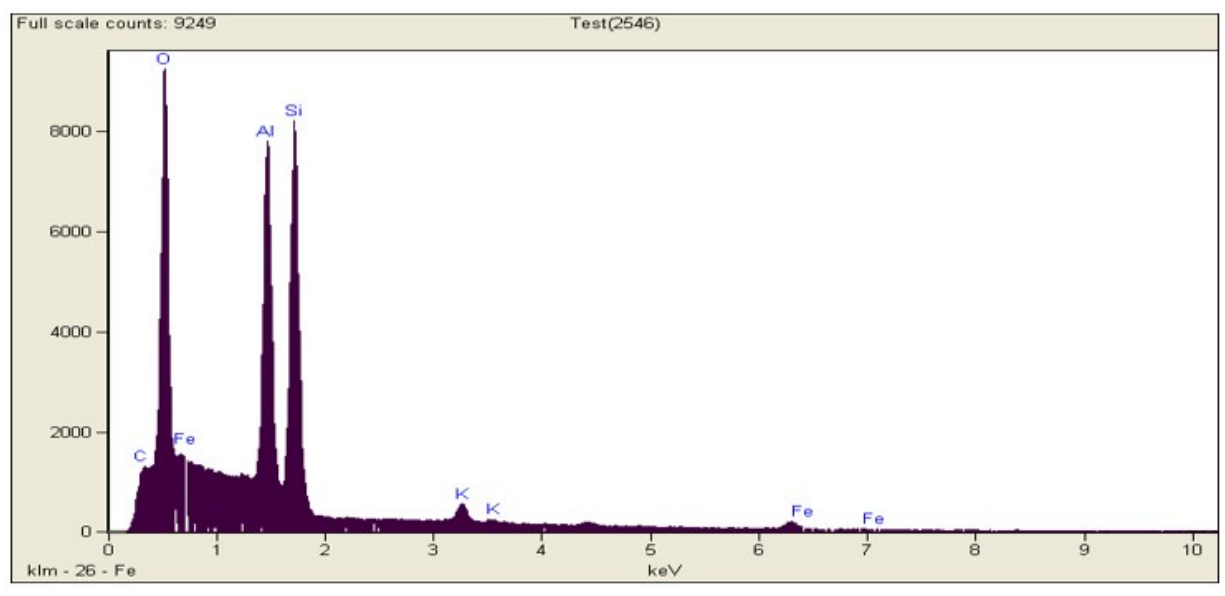

Figure 1. Elemental mapping of the kaolin clay determined using EDX. The respective colour codes represent individual element. 
meq/100 g support, while N-MK exhibits a CEC of $1.5 \mathrm{meq} / 100$ support. The CEC for NK is within the range of CEC values of between 2$10 \mathrm{meq} / 100 \mathrm{~g}$ support, as reported in the literatures [34,35].

The considerably high CEC in a number of kaolinite clays is attributed to the presence of smectite layers on the kaolinite crystal surfaces [35]. The high CEC is also due to the edges of crystals in kaolin, where imperfection essentially occurs as a result of bond breakage which are electrophilic and capable of trapping $\mathrm{OH}$ groups in water [36]. These correspond to the formation of silanol, $\mathrm{Si}-\mathrm{OH}$ and aluminol,
$\mathrm{Al}-\mathrm{OH}$ groups at the edges of the clay platelets which are able to fix cations in solutions. Besides that, trapping of cations can also occur by defect on the basal planes of the kaolin clay [37].

Following thermal treatment, the CEC decreased by $1.0 \mathrm{meq} / 100 \mathrm{~g}$ from NK to N-MK due to the dehydroxylation reaction during heat treatment. At this stage, $\mathrm{OH}$ groups and $\mathrm{H}^{+}$in the interlayers between cations in kaolinite were removed as water molecules, resulting in a substantial reduction in the number of adsorption sites upon heat treatment [36,37].

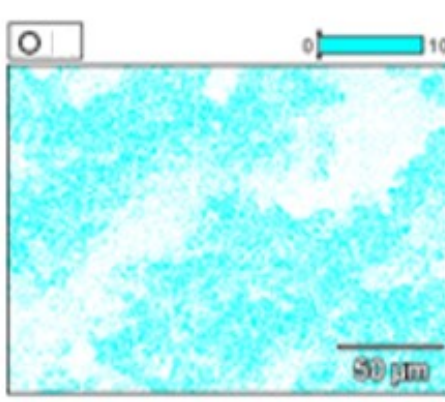

Oxygen

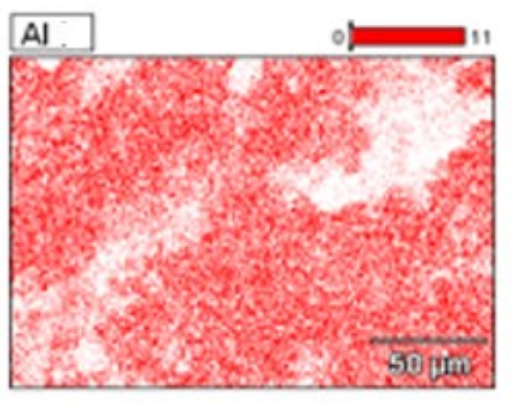

Aluminum

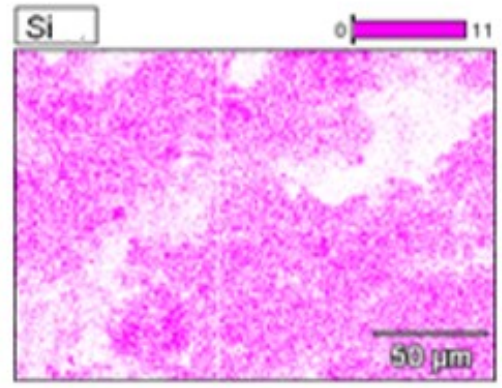

Silicon

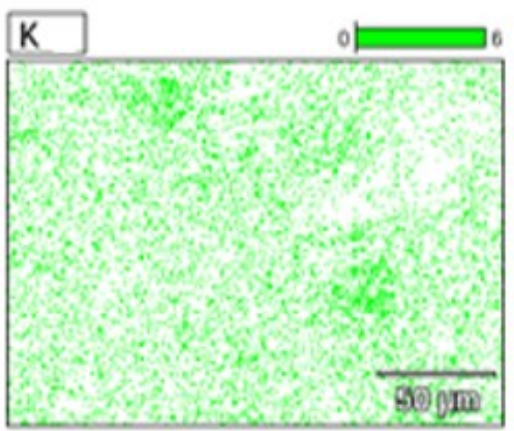

Potassium

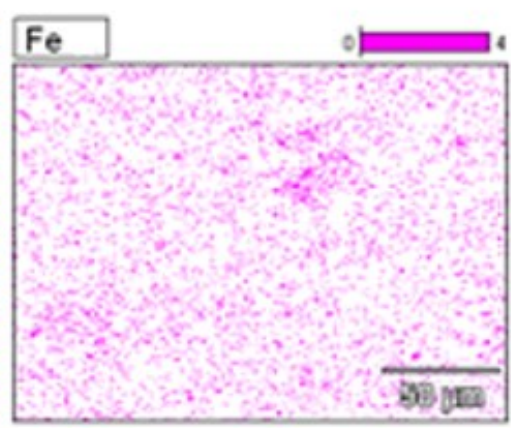

Iron

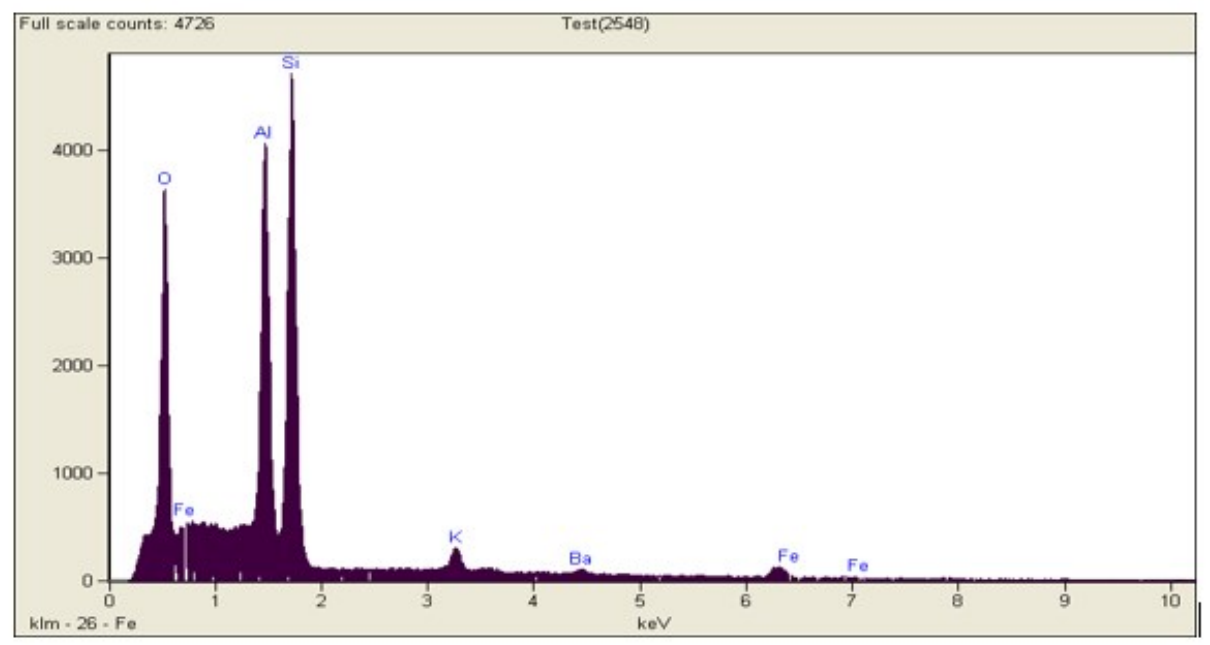

Figure 2. Elemental mapping of the metakaolin clay determined using EDX. The respective colour codes represent the individual element 
3.3 Characterization of the Supports and Immobilized CRL Biocatalysts

3.3.1 Characterization using X-ray Diffraction Analysis (XRD)

XRD patterns of supports and immobilized CRL are as shown in Figure 3. In Figure 3(a), it can be seen that NK is predominantly constituted by quartz, together with a small amount of kaolinite, muscovite and anatase, revealing the crystalline nature of the support. A similar XRD pattern of kaolin clay was also observed by Boukhemkhem and Rida [38]. The presence of muscovite, $\mathrm{KAl}_{2}\left(\mathrm{AlSi}_{3} \mathrm{O}_{10}\right)(\mathrm{OH})_{2}$, in the kaolin $\mathrm{XRD}$ patterns is in correlation with the detection of potassium in the analysis using EDX spectroscopy technique. The peak at $2 \theta=$ $12.46^{\circ}$ is the distinctive XRD pattern for kaolinite mineral.
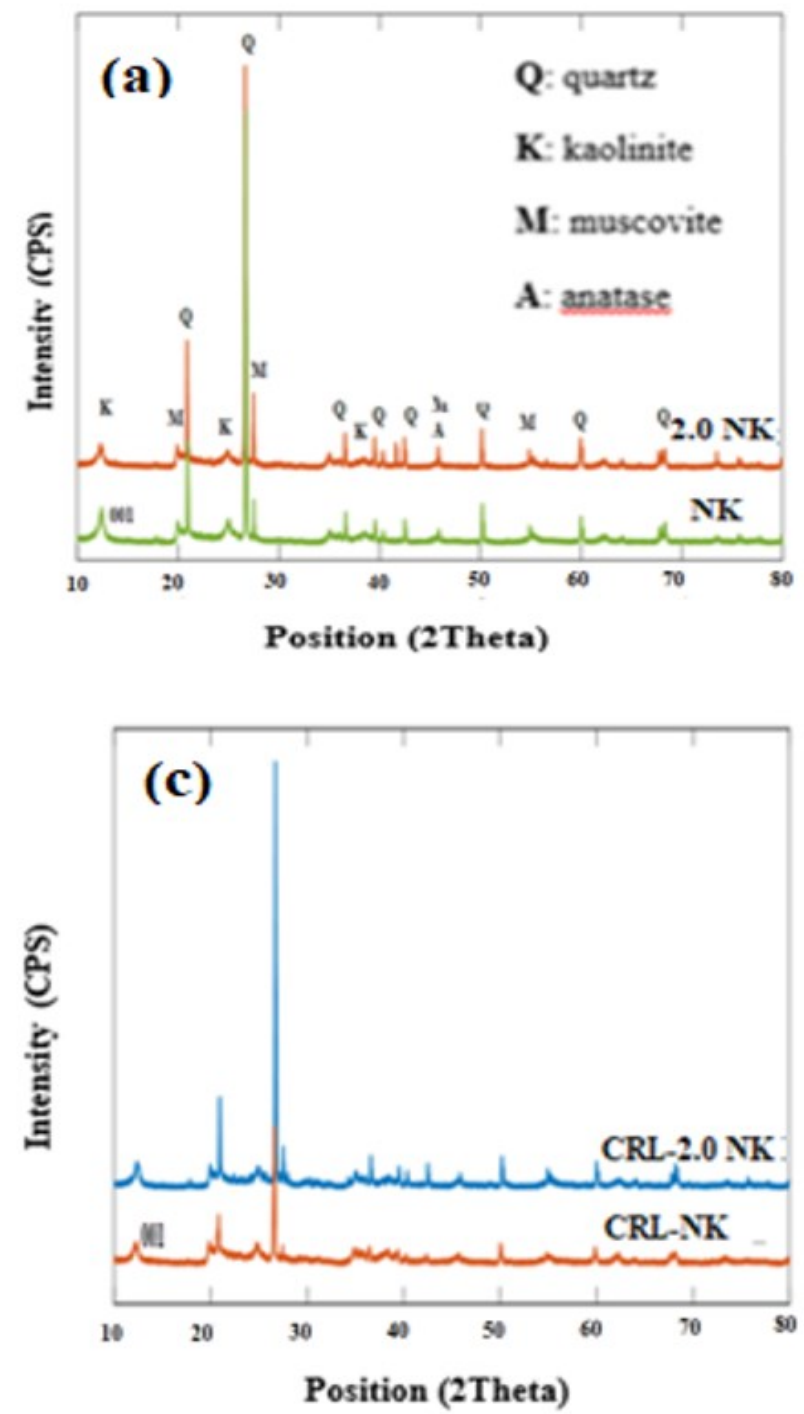

Table 2 shows the $d$-spacing values for NK and its derivatives. The $d$-spacing value for NK was found to be $7.12 \AA$. After modification with $\mathrm{BTEA}^{+}$the $d$-spacing of $\mathrm{NK}$ increased to 7.20 A. Jahan et al. [40] reported that the expansion of the interlayer space in the clay structure was due to the ammonium salt intercalation.

Table 2. Value of $d$-spacing for kaolin and its derivatives.

\begin{tabular}{cccc}
\hline Sample & $2 \theta$ & $d_{(001)} \AA$ & Intensity \\
\hline NK & 12.46 & 7.12 & 341.48 \\
$2.0 \mathrm{NK}$ & 12.28 & 7.20 & 107.97 \\
CRL-NK & 12.26 & 7.22 & 166.63 \\
CRL-2.0 NK & 12.44 & 7.11 & 178.55 \\
\hline
\end{tabular}

$d$-spacing values were extracted at $2 \theta=\sim 12.4^{\circ}$ from the XRD patterns.
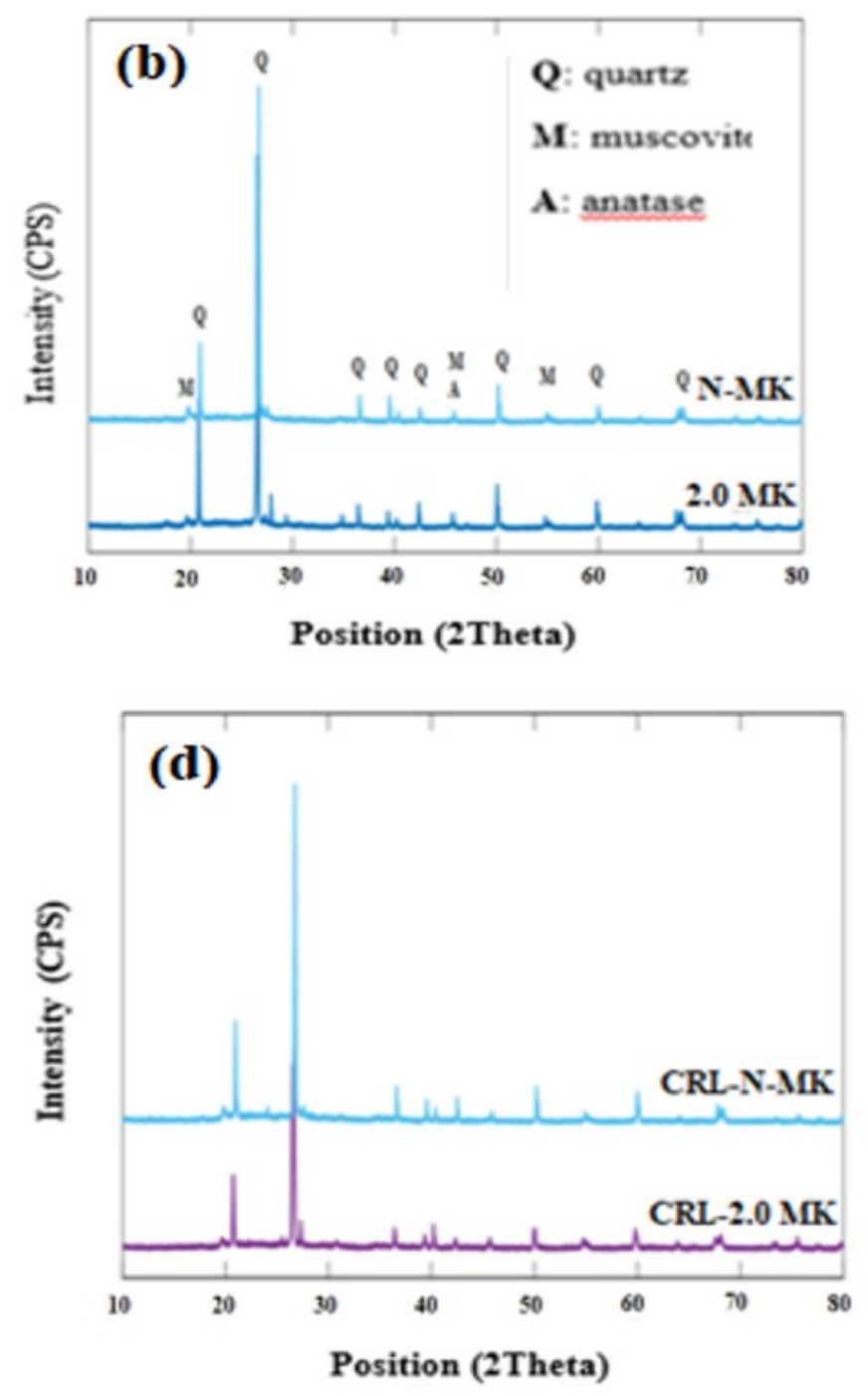

Figure 3. XRD patterns for the immobilization supports and immobilized CRL 
Looking at the slight difference in the $d$ spacing between NK and $2.0 \mathrm{NK}(0.08 \AA$ \&), it can be concluded that not all $\mathrm{BTEA}^{+}$cations were incorporated in the interlayer spaces of the kaolin clay. This is common among kaolinite clay which possesses relatively smaller $d$-spacing as compared to bentonite and other clays [41].

Interestingly, after thermal treatment the characteristic diffraction peaks of kaolinite at $2 \theta=12.4^{\circ}$ disappeared, indicating that the kaolinite had undergone structural realignment upon heating. This is because, the calcination of kaolinite which took place had been accompanied by structural water loss with structural reorganization causing the original triclinic cell to collapse, leaving only a small portion of $\mathrm{AlO}_{6}$ octahedral structure, while the rest of the structure have been converted into tetrahedral $[19,42,43]$.

Table 2 also shows that immobilization of lipase on NK and 2.0 NK did not cause significant changes in d-spacing of the samples. Immobilization of CRL had caused decrease in the intensities of the XRD patterns as a result of CRL loading (Figure 3(c) and Figure 3(d)),
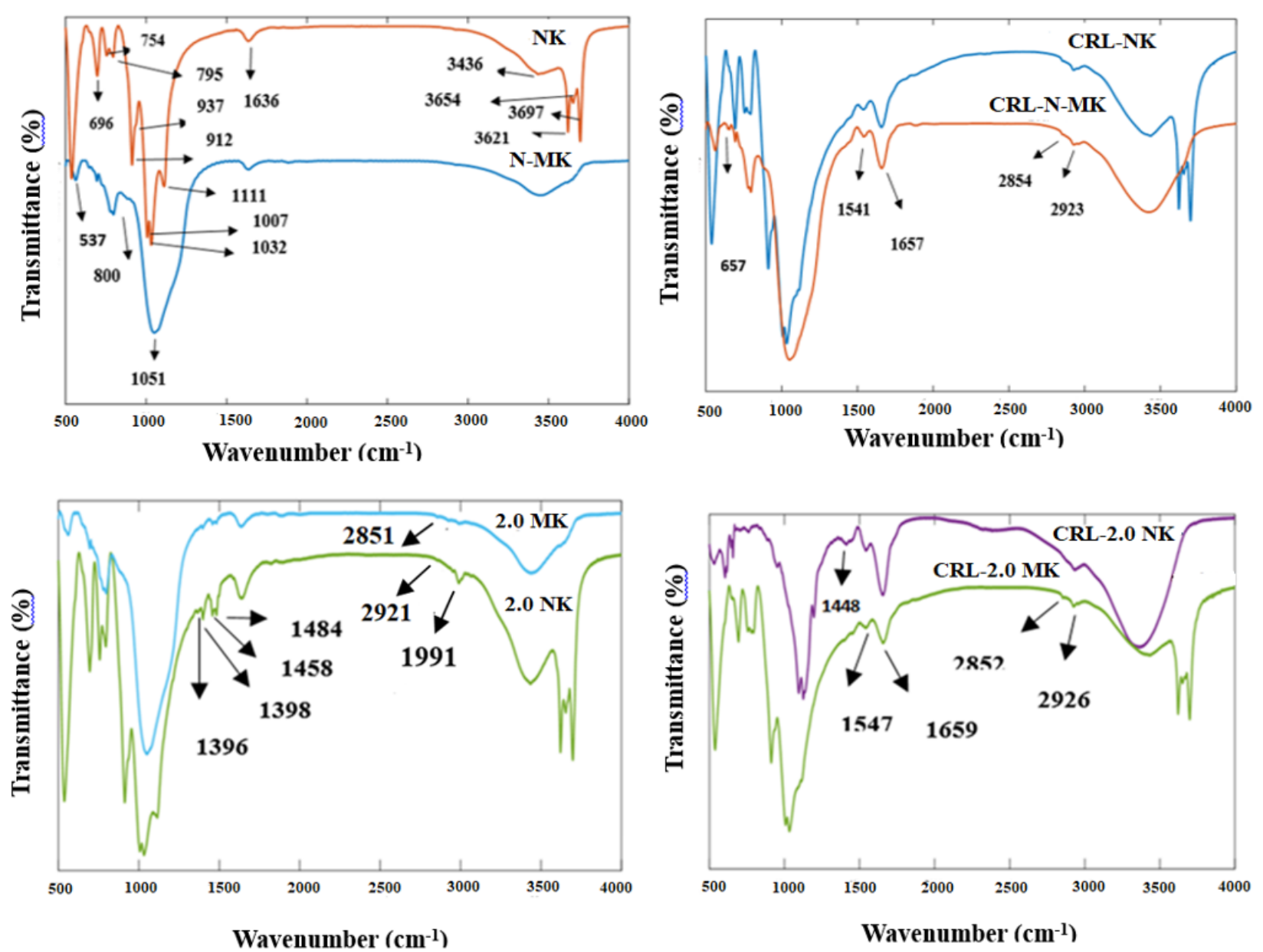

Figure 4. FTIR spectrum for the immobilization supports and biocatalysts.

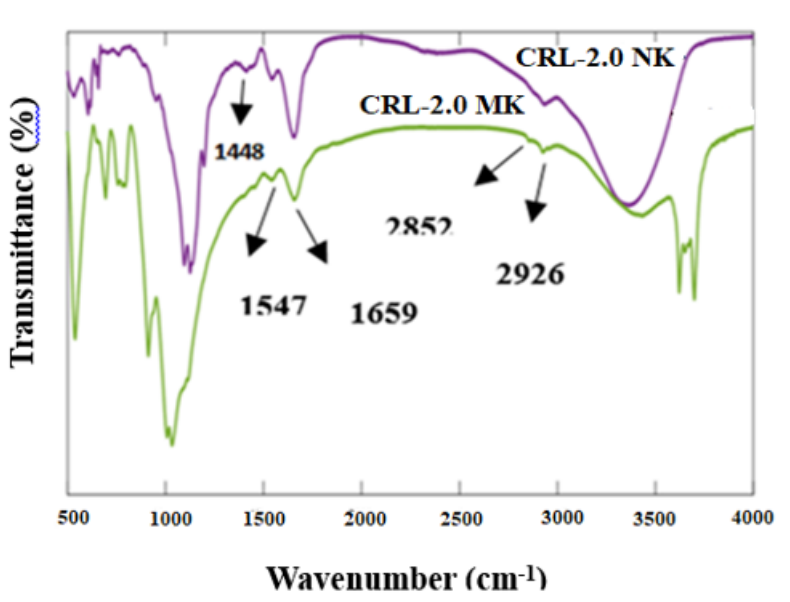

which had led to decrease in the surface crystallinity. However, XRD patterns were found to remain as it was before the immobilization process, and this is in agreement with the finding by Zhang et al. [44].

The slight changes in the $d$-spacing and the maintained XRD peaks upon immobilization of lipase is expected due to the globular protein size of the CRL enzyme molecule (50-70 $\AA$, with molecular weight of $60 \mathrm{kDa}$ ) as compared to the d-spacing of NK and 2.0 NK. During immobilization, the side chains of various amino acid residues could have been participated in the intercalation whereas the polypeptide backbone may have been immobilized at the external surface and the edges of the clay.

\subsubsection{Characterization Using Fourier Trans-} form Infrared (FTIR) Spectrometer.

FTIR spectra of all samples are as presented in Figure 4. From the characterization of NK, bands at 3697 and $3654 \mathrm{~cm}^{-1}$ in the FTIR spectrum were attributed to the hydroxyl groups on the surface of the clay, while band at $3621 \mathrm{~cm}^{-1}$ corresponded to the stretching of the 
internal hydroxyl groups. The band with large intensities at region between $3620-3690 \mathrm{~cm}^{-1}$ matched well with the bands of crystallized kaolinite as reported by Kakali et al. [45]. On the other hand, bands at $3436 \mathrm{~cm}^{-1}$ together with the band at $1636 \mathrm{~cm}^{-1}$ were caused by the stretching and bending vibrations of free water molecules located at the surface of kaolin. The bands at $937 \mathrm{~cm}^{-1}$ and $912 \mathrm{~cm}^{-1}$ were assigned to the bending of the inner hydroxyl groups connected to $\mathrm{Al}$, while the bands at 795,754 , 696 and $537 \mathrm{~cm}^{-1}$ corresponded to the vibrations of $\mathrm{Si}-\mathrm{O}-\mathrm{Al}$ groups [38]. The bands that appeared at 1111, 1032, and $1007 \mathrm{~cm}^{-1}$ corresponded to the $\mathrm{Si}-\mathrm{O}-\mathrm{Si}$ molecule.

For the characterization of N-MK, major changes can be clearly seen in the FTIR spectrum as a result of the thermal treatment, where bands attributed to internal and external hydroxyl groups were found to be disappeared as a result of the treatment which has led to dehydroxylation of kaolin clay. As a result, all peaks that matched the existence of $\mathrm{Si}-\mathrm{O}-\mathrm{Si}$ groups were found gathered as one large band at $1051 \mathrm{~cm}^{-1}$ due to the formation of amorphous silica in the structure. Bands at 912 and $937 \mathrm{~cm}^{-1}$ which initially existed in FTIR spectra of NK also disappeared in the FTIR spectra of N-MK as a result of the loss of Al-OH molecules in the alumina octahedral structural sheet, an indication that the silica tetrahedral sheet remained unchanged in the structure [46]. In addition, minor band at $537 \mathrm{~cm}^{-1}$ along with shifted band at $795 \mathrm{~cm}^{-1}$ to $800 \mathrm{~cm}^{-1}$ appeared as a result of changes which occurred in the aluminum coordination which unambiguously showed that dehydroxylation had occurred [13].

The characteristic bands of both clays were still maintained even after organo-modification with $\mathrm{BTEA}^{+}$, indicating the retained structure of the clays as analyzed using XRD. On the other hand, it can be seen that widths and the positions of peaks that correspond to hydroxyl stretching and hydroxyl-deformation modes of the clay mineral changed, suggesting the reaction between kaolin hydroxyl groups with $\mathrm{BTEA}^{+}$. FTIR spectra for organo-modified kaolin showed that the $\mathrm{Si}-\mathrm{O}$ stretching band shifted from $1111 \mathrm{~cm}^{-1}$ to $1116 \mathrm{~cm}^{-1}$, while the intensity of the band of at $1032 \mathrm{~cm}^{-1}$, which corresponded to $\mathrm{Si}-\mathrm{O}-\mathrm{Si}$, significantly decreased. However, the bands assigned to $\mathrm{Si}-\mathrm{O}$ stretching modes, are extremely robust and it is not easy to get more information on the alterations resulting from the interaction with the surfactant.
The band corresponding to the ammonium salt utilized is presented in the range of between $2991-2982 \mathrm{~cm}^{-1}$; but this band usually exist in low intensity in the spectra of organoclays. Bands with low intensities near 2851 and $2921 \mathrm{~cm}^{-1}$ can be assigned to the symmetric and asymmetric stretching vibrations of the methylene group of the guest molecules. These bands confirmed the occurrence of interactions between the ammonium molecules and the clay samples [47]. The additional pair of characteristic bands at 1484 and $1398 \mathrm{~cm}^{-1}$ was due to the torsion of the $\mathrm{C}-\mathrm{H}$ bonds, which is not present in the spectrum of the starting clay sample. The band around $1458 \mathrm{~cm}^{-1}$ is assigned to $\mathrm{CH}_{3}$ asymmetric bending. According to Mota et al. [48], the presence of $\mathrm{CH}_{2}$ and $\mathrm{CH}_{3}$ groups in the infrared spectrum of organo-clay is clear testimony to the intercalation of the ammonium quaternary cation of the surfactant within the clay samples. In comparison between the NK and N-MK, the changes in the FTIR spectrums indicate that the presence of organic groups as a result of successful modification using BTEA-Cl.

After immobilization of CRL, the absorption bands linked to the $-\mathrm{C}=\mathrm{O}$ stretching was likely disrupted by the existence of the bending vibrations at $1636 \mathrm{~cm}^{-1}$, causing higher intensity of the $-\mathrm{C}=\mathrm{O}$ peak of the immobilized lipases (1657-1659 $\left.\mathrm{cm}^{-1}\right)$. A peak around 1541-1550 $\mathrm{cm}^{-1}$ was ascribed to the $-\mathrm{NH}$ bending vibration of the peptide bonds, while bands at around 2850-2854 $\mathrm{cm}^{-1}$ and $2920-2938 \mathrm{~cm}^{-1}$ appear to confirm the existence of $-\mathrm{C}-\mathrm{H}$ group. These bands are an indication of asymmetric stretching vibration of aliphatic $\mathrm{C}-\mathrm{H}$ group with contributions from the organo-surfactant, and the enzyme [49,50]. The band at $1448 \mathrm{~cm}^{-1}$ was assigned to $\mathrm{C}-\mathrm{H}$ deformation vibrations of alkyl groups and originating from the adsorbed lipase molecules. It is therefore confirmed that modifications and immobilization have taken place band on the functional groups in the spectra.

\subsubsection{Characterization Using Scanning Elec- tron Microscope (SEM)}

The surface morphologies of the supports, and immobilized lipases were observed using scanning electron microscope at 100,000x magnifications as shown in Figure 5. The micrograph of NK in Figure 5(a), described as distorted platelets, consisting of laminar particle aggregates of varying sizes and thicknesses. This indicates that the particles are not fully dispersed into individual layers. The platy 

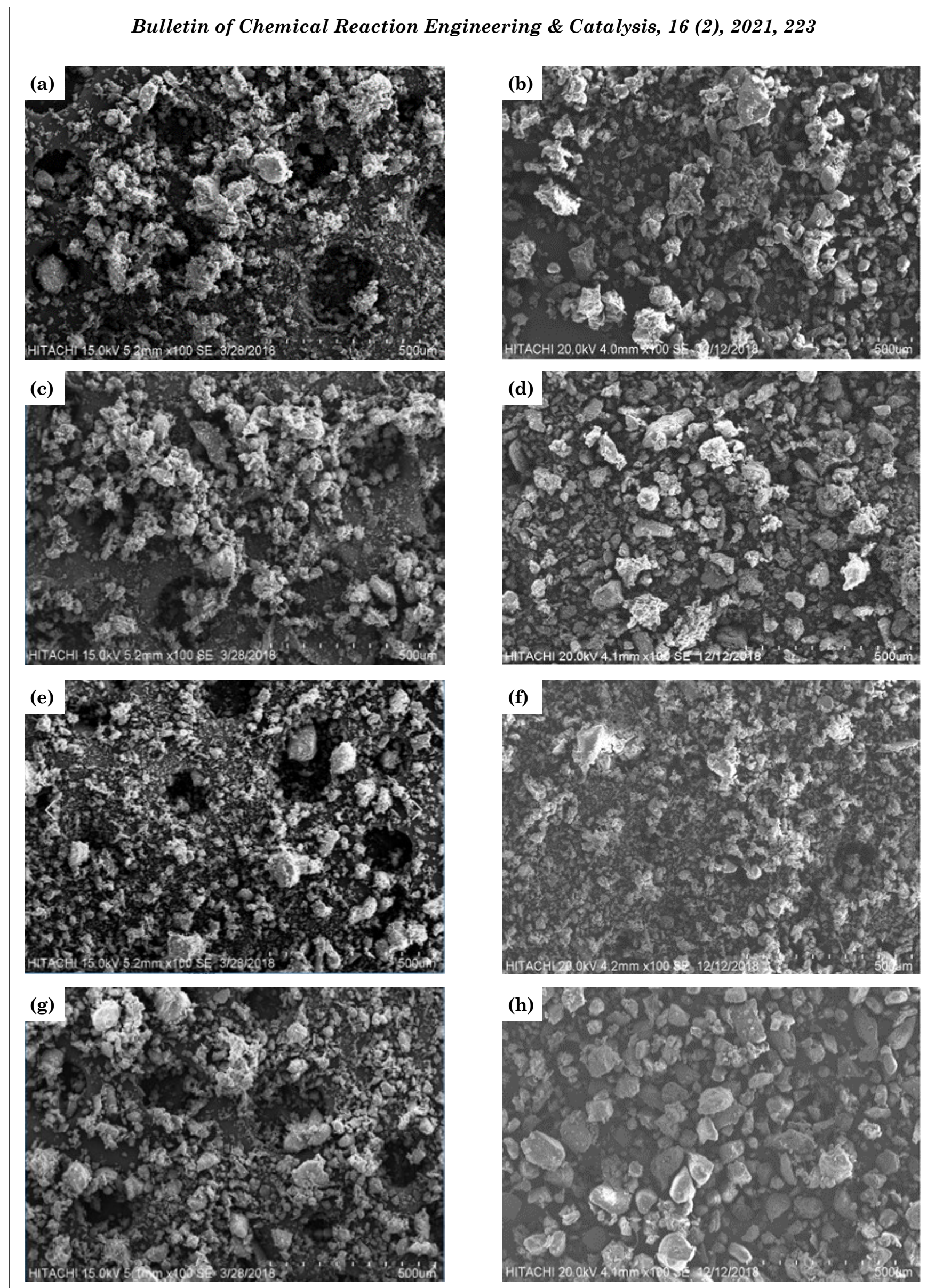

Figure 5. Scanning electron micrographs of the immobilization supports (a) NK, (b) N-MK, (c) 2.0 NK, (d) $2.0 \mathrm{MK}$ and biocatalysts (e) CRL-NK, (f) CRL-MK, (g) CRL-2.0 NK, (h) CRL-2.0 MK at 100,000x magnifications. 
structures are closely packed together and reducing voids between the particles. Such association development is likely because of the domination of hydrogen bonds. The particles after thermal treatment (N-MK) (Figure 5(b)) are considerably larger than NK. Disorganization of the crystalline structure of the material occurs with no substantial alteration to the morphology of the kaolin platelets, and more voids are seen as a result of heating the kaolin at 650 ${ }^{\circ} \mathrm{C}$ for $5.0 \mathrm{~h}$. Konan et al. [37] noticed that the thermal treatment does not modify drastically the morphology of kaolin sample.

It can be seen that the clay surface has no aggregated morphology after organomodification (Figure 5(c) and (d)), and there was an increased in individualized platelets. Lipase was found to give a change in the morphology of the supports (Figure 5(e)-(h)), where was increased in particle size after immobilization process. However, not much change on porosity can be visualized which is in accordance to that observed after enzyme immobilization on montmorillonite K10 [51]. Furthermore, the outer surface of the supports used turned substantially thicker with formation of larger a greater following immobilization because of the accumulation of lipase molecules on the support surface.

\subsubsection{Characterization Using Nitrogen Adsorp- tion/Desorption Analyser}

The outcomes of the physico-chemical analysis (surface area, pore volume, and pore size) for all samples are summarized in Table 3. The decrease in surface area after thermal treatment could be caused by dehydroxylation which leads to the collapse of kaolin layers that bringing particles closer to one another. This leads to the agglomeration phenomenon among particles. As the aggregated particles begin to sinter, the surface area begins to decrease. The increase in pore volume and pore size after ther- mal treatment was as a result of loss of water and the formation of wider interparticle voids, which contribute more to volume expansion than to the surface area expansion [52]. The organo-modification however leads to decrease in surface area and pore volume of the modified clay samples, which is in agreement with the previous work by Ramos et al. [41]. These results support the idea that the organic moieties of the BTEA-Cl surfactant are covalently linked to the edge of $-\mathrm{OH}$ groups of individual clay platelets, which may eclipse parts of the clay surface, making it inaccessible during nitrogen adsorption [53].

In addition, the pore blocking effect also led to decrease in the BET surface area, where the higher amount of exchanged cation may clog more smaller pores of the clay. The lower pore volumes of the 2.0 NK and 2.0 MK compared to $\mathrm{NK}$ and N-MK was related to pore fillings by the macromolecules of $\mathrm{BTEA}^{+}$[52,53]. Although the modification by the cation exchange process resulted in lowering of surface area and pore volume of the NK and N-MK, the modified clays exhibited increased pore sizes. These results indicate that the $\mathrm{BTEA}^{+}$molecule may have been mainly inserted in the mesopore spaces of the clay.

Figures 6 and 7 show the nitrogen sorption isotherms for NK, MK, $2.0 \mathrm{NK}$ and 2.0 MK. The isotherms of unmodified clay samples were found to belong to the Type IV isotherm with narrow hysteresis loop of H3 type, which is typical of porous solids consisting particle aggregates. The modified samples showed a similar patterns of isotherm and hysteresis loops to that of unmodified clays. This indicates that the porous structure of clay is still maintained even after the cation exchanged reaction, as proven by using XRD and SEM results. The low amounts of $\mathrm{N}_{2}$ adsorbed at relative pressures, $P / P_{0}<0.2$ indicated the absence of microporosity in the kaolin clay. The rapid in-

Table 3. Physical properties of the supports and immobilized CRL.

\begin{tabular}{cccc}
\hline Sample & Surface area $\left(\mathrm{m}^{2} / \mathrm{g}\right)$ & Pore volume $\left(\mathrm{cm}^{3} / \mathrm{g}\right)$ & Pore size $(\AA)$ \\
\hline NK & 25.34 & 0.113 & 179 \\
N-MK & 19.91 & 0.121 & 225 \\
$2.0 \mathrm{NK}$ & 5.90 & 0.054 & 385 \\
$2.0 \mathrm{MK}$ & 9.04 & 0.098 & 413 \\
CRL-NK & 8.16 & 0.087 & 315 \\
CRL-N-MK & 9.77 & 0.093 & 402 \\
CRL-2.0NK & 2.22 & 0.031 & 673 \\
CRL-2.0MK & 3.69 & 0.048 & 710 \\
\hline
\end{tabular}


crease in the volume of $\mathrm{N}_{2}$ adsorbed beginning from $P / P_{0} \sim 0.8$ was due to the filling of the mesopores of the largest particle in the clay as well as those particles located at the surface of the clay [54]. The sharpness towards $P / P_{0}=1.0$ indicated the uniformity of the mesopore size distribution, a typical phenomenon shown by mesoporous materials [55]. Duarte-Silva et al. [43], reported a similar behaviour for their kaolin sample. Pore size distribution curves from adsorption isotherm of unmodified kaolin, metakaolin and organo clay samples are illustrated in Figure 8. According to IUPAC definition these pores are related to mesopores range (diameter of 20-500 $\AA$ ). Adsorption of CRL led to substantial decline in the surface area and mesopore volume of the resultant catalysts, indicating the adherence of the enzyme on the cavities of the supports. These findings could be also due to the layered structure of clay samples that has been collapsed during the immobilization process [56,57].

\subsection{Effect of Support Modification on the Per- centage of Immobilization}

The percentage of immobilization on the support materials, calculated based on amount of protein, is shown in Table 4. Among the support used, 2.0 MK displayed the highest protein loading of $14.83 \pm 1.37 \mathrm{mg}$ protein/g support and achieved up to $70.14 \pm 2.41 \%$ immobilization. Meanwhile, 2.0 NK showed the lowest percent-

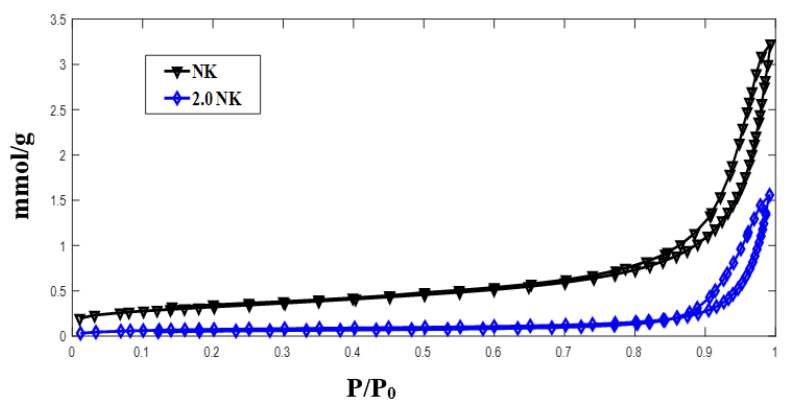

Figure 6. Nitrogen adsorption/desorption isotherms of unmodified kaolin (NK) and organomodified kaolin (2.0 NK). age of lipase immobilization at $47.83 \pm 1.52 \%$. These results were better compared to the results obtained by Musa et al. [6], who achieved about $31.2 \%$ of immobilization of Pseudomonas AMS8 lipase on kaolin.

The high percentage of CRL immobilized onto 2.0 MK was due to the larger pore size of the support, suitable to accommodate large biomolecules such as CRL. Furthermore, the porous structure of 2.0 MK enables a large quantity of the enzyme to be immobilized onto it. In contrast, supports with smaller pore sizes, such as $2.0 \mathrm{NK}$, may restrict mass transfers and penetration of enzyme molecules into and out of the pores of the support, resulting in limited protein adsorbed [6]. The low amount of protein adsorbed onto $2.0 \mathrm{NK}$ was related to the limited amount of organo surfactant found in its interlayer after modification. This result appeared to be similar to that obtained by Ramos et al. [41], who studied the use of organobentonite as support to immobilize CRL. In their study, $48 \%$ of CRL was approximately immobilized onto raw bentonite as compared to $81 \%$ immobilization onto modified bentonite. This downward trend with regards to the raw, unmodified clay may be caused by the aggregation of CRL during excessive lipase interaction with the support, which impeded the adsorption of protein [44,58]. Support modification and immobilization of CRL as illustrated in our previous work [59] is shown in Scheme 1.

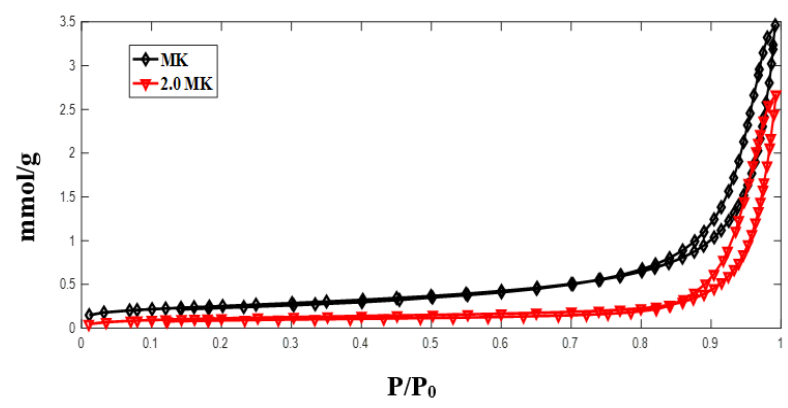

Figure 7. Nitrogen adsorption/desorption isotherms of unmodified metakaolin (MK) and organo-modified metakaolin (2.0 MK).

Table 4. Protein loading on clay supports and its effect on lipase specific activity upon immobilization.

\begin{tabular}{cccc}
\hline Lipase derivatives & $\begin{array}{c}\text { Protein loading } \\
\text { (mg protein / } \\
\text { support) }\end{array}$ & Immobilization (\%) & $\begin{array}{c}\text { Specific activity (mmol } \\
\text { ester/min/mg) }\end{array}$ \\
\hline CRL & - & - & $3.27 \times 10^{-3}$ \\
CRL-NK & $7.51 \pm 0.38$ & $52.99 \pm 1.17$ & $3.63 \times 10^{-3}$ \\
CRL-N-MK & $7.84 \pm 0.44$ & $55.50 \pm 0.54$ & $4.08 \times 10^{-3}$ \\
CRL-2.0NK & $5.85 \pm 0.12$ & $47.83 \pm 1.52$ & $4.97 \times 10^{-3}$ \\
CRL-2.0MK & $14.83 \pm 1.37$ & $70.14 \pm 2.41$ & $5.24 \times 10^{-3}$ \\
\hline
\end{tabular}



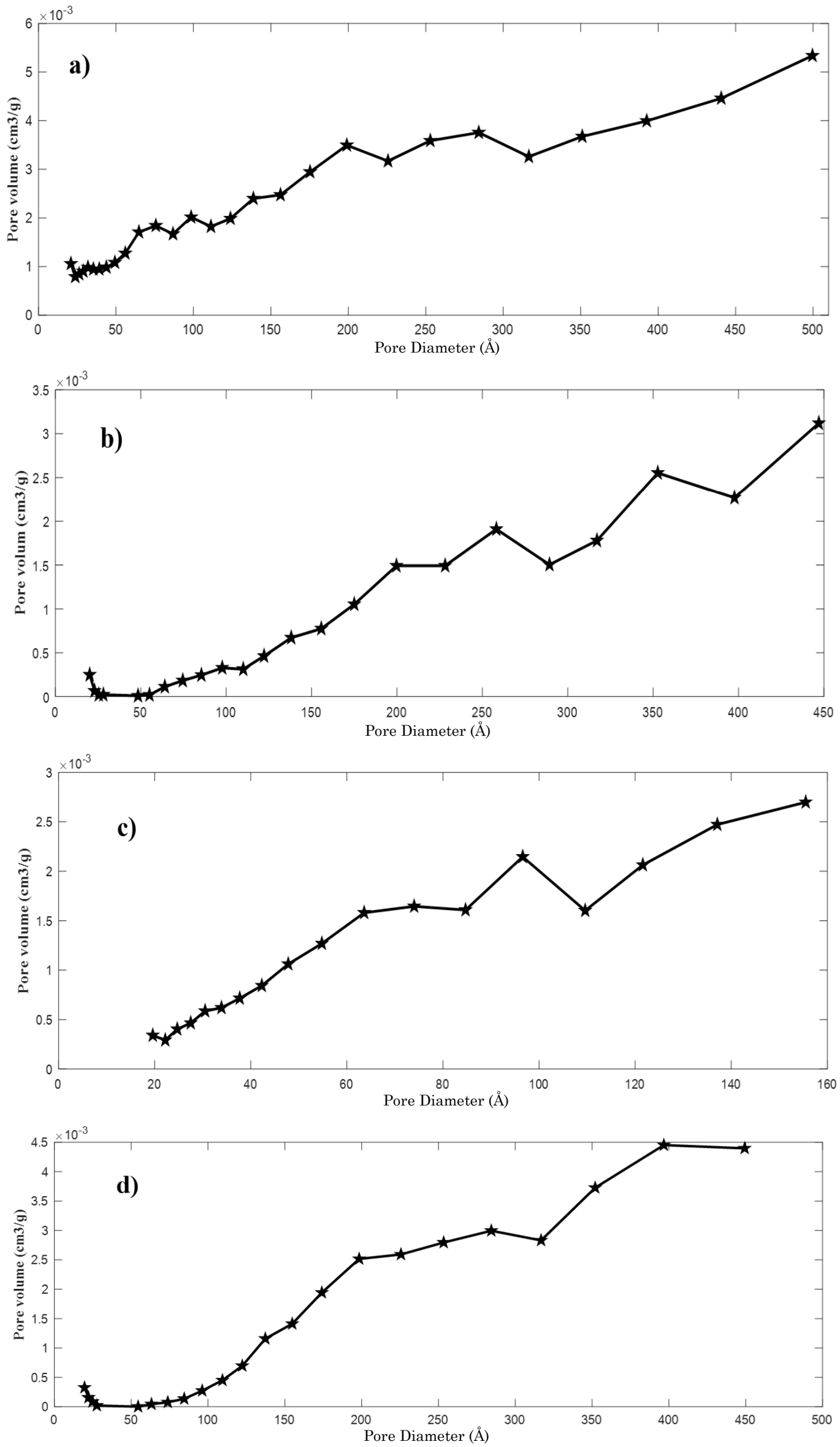

Figure 8. Pore size distributions of (a) NK, (b) $2.0 \mathrm{NK}$, (c) N-MK and (d) $2.0 \mathrm{MK}$ 
In this present study, percentage of immobilization on N-MK $(55.50 \pm 0.54 \%)$ which was slightly higher than on NK $(52.99 \pm 1.17 \%)$, was related to the higher pore size of N-MK $(225 \AA)$, as compared to NK (179 ̊), shown in Table 2 . Increase in pore size of N-MK as a result of heat treatment on NK was similar to the finding by Ajayi et al. [25]. Heat treatment carried out on the clay also makes it less acidic and more suitable for accommodation of enzyme [59].

\subsection{Activity Assay on Free and Immobilized CRL}

In general, the catalytic activities of immobilized CRL were higher compared to the free CRL, when used in the esterification reaction between nonanol and hexanoic acid. This is mainly due to the higher surface areas provided by the supports which lead to wider distributions of lipase. This then leads to better exposure of the enzyme active-site towards the reactants. Meanwhile, free CRL tends to form aggregates because it is insoluble in organic medium $[12,60]$.

As shown in Figure 9, the efficacies of the immobilized CRL were in the following sequence: CRL-2.0 MK > CRL-2.0 NK > CRL-NMK $>$ CRL-NK $>$ CRL, with lipase adsorbed onto organo-kaolin (CRL-2.0 NK) and organometakaolin (CRL-2.0 MK) exhibiting substan- tially enhanced catalytic efficacies. This was due to interfacial activation of the enzyme after its adsorption onto the hydrophobic organo-clay samples, which leads to open conformation of the enzyme active site [51]. In a report by Öztürk et al. [61], interactions between the enzyme molecules with the organo-modifier (ammonium salt) on modified clays causes improved conformation and orientation of enzyme, promoting better access of its active centre.

Non-surprisingly, CRL-NK showed the low-

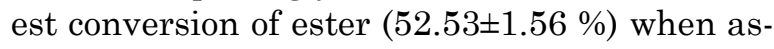
sayed in the reaction to synthesis nonyl hexanoate. The comparably low ester conversion might be due to its negatively charged surface, which may not be appropriate for enzymes [23]. This is in agreement with the results obtained by Musa et al. [6], where the kaolin support exhibited lowest efficacy in the synthesis of ethyl hexanoate in comparison with other supports. Unsuitability of this support towards enzymes such as porcine pancreatic lipase and acid phosphatase was also discussed by other researchers [21-23].

Interestingly, the high amount of protein loaded onto a support does not necessarily reflect the efficacy of the enzyme [56]. This was observed in the use of CRL-2.0 MK, where 2.0 MK showed the highest adsorption ability of about $70 \%$ but exhibited an almost similar spe-

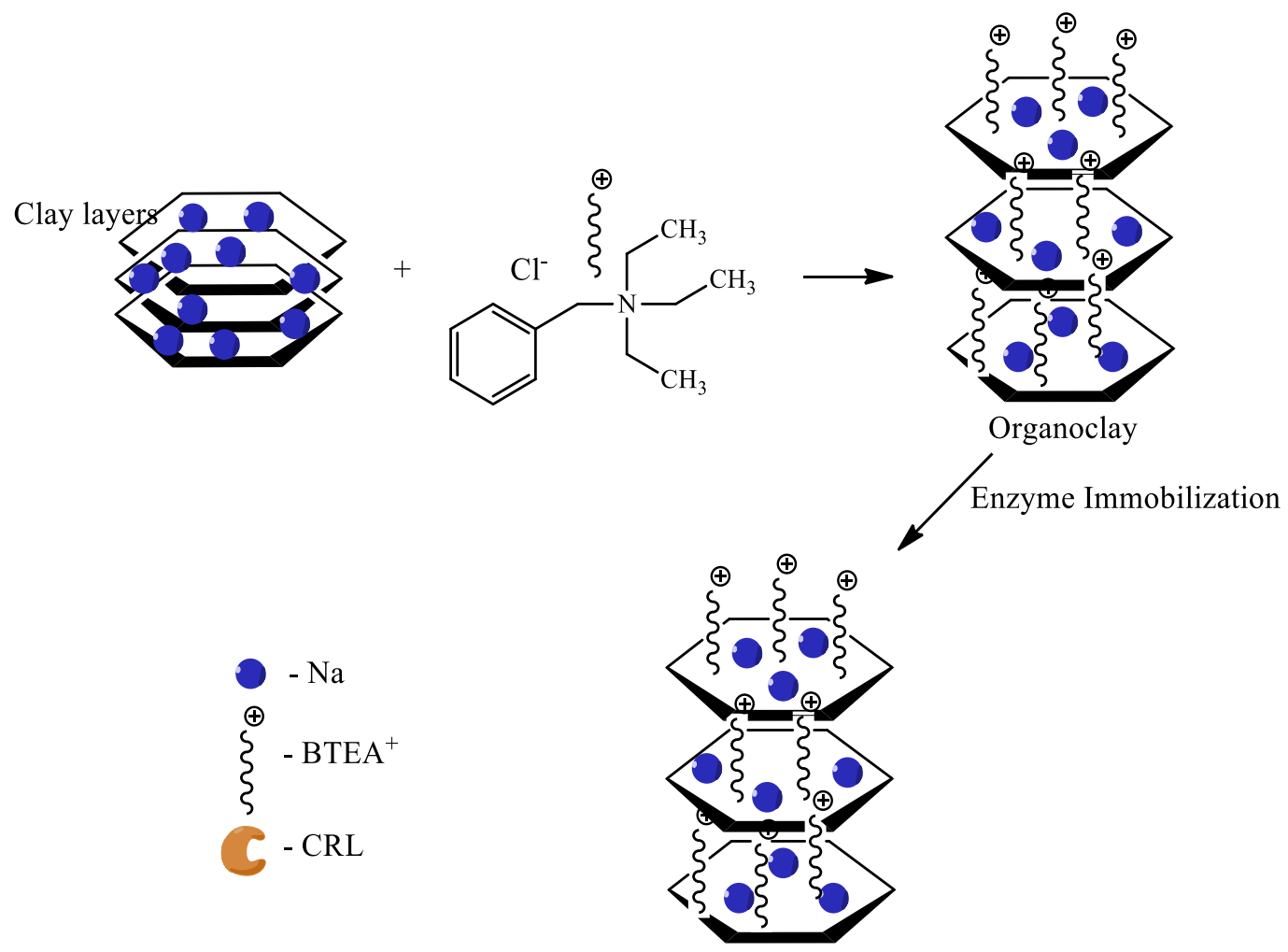

Scheme 1. A schematic diagram illustration of kaolin modification and lipase adsorption [59] 
cific activity and ester conversion to CRL-2.0 NK. This was probably due to the following factors: (a) formation of enzyme aggregates on the surface of 2.0 MK, where distribution of enzymes are not even; (b) distortion of enzyme tertiary structure due to strong interaction with support; (c) structural damage of protein caused by the protein-protein interactions which are the consequence of deficit in space between adsorbed proteins; (d) excess of loaded enzyme molecules which may have formed thick layers of adsorbed lipases resulting in loss of activity to those enzymes less accessible to substrates [61].

According to Paul et al. [62], the biggest impact of structural porosity is associated with the internal environment where substrates are well dispersed towards the active site of the entrapped enzyme and back into the reaction medium. This is however restricted in supports with narrow pores, where they find constrain in mass transfer in all directions. Amongst the kaolin clay derivatives, $2.0 \mathrm{NK}$ and 2.0 MK possess pore sizes large enough to overcome limitations of the inherent diffusion.

\subsection{Thermal Stability}

The stability of enzyme at high temperatures can extend its applications in industry. One of the aims of immobilization of enzyme is to improve its thermal stability. In this study, CRL immobilized onto 2.0 NK and 2.0 MK were selected for thermal stability assay due to their high specific activities and ester conversions in the esterification reactions that they catalyzed. As shown in Figure 10, the relative activity of free CRL drastically decrease to below $50 \%$ of its initial activity when reaction was conducted using CRL pre-incubated at $50{ }^{\circ} \mathrm{C}$. Relative ac-

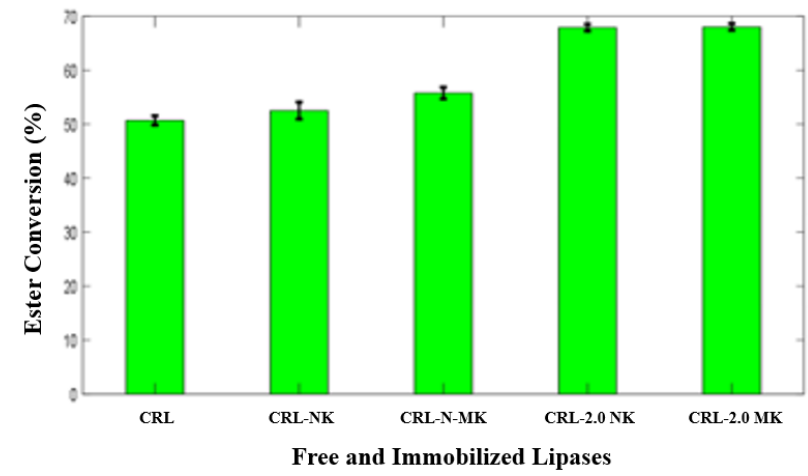

Figure 9. Ester conversion as exhibited by free and immobilized CRL in the synthesis of nonyl hexanoate. The reactions were performed in triplicates at $30{ }^{\circ} \mathrm{C}$ for $5 \mathrm{~h}$ with equal amounts of substrates $(2.0 \mathrm{mmol})$. tivity of the free lipase continued to decrease to $32.69 \%$ and $28.13 \%$, when CRL pre-incubated at $60{ }^{\circ} \mathrm{C}$ and $70{ }^{\circ} \mathrm{C}$ were used, respectively. As for the immobilized CRL, these enzymes were found to retain high relative activities of between $80.59 \%$ to $89.32 \%$ when immobilized lipase pre-incubated at temperatures between $50{ }^{\circ} \mathrm{C}$ to $70{ }^{\circ} \mathrm{C}$ were used. The improved thermostabilities of immobilized CRL were related to the hydrophobic interactions between the enzyme molecules and the organo-modified clay supports [18].

Based on results obtained, immobilization of enzyme has indeed helped to minimize negative effects of high temperatures due to the protected structure of the enzyme against thermal degradation by the support. As such, enhancement of the enzyme resistance against heat is attributed to its multiple attachment points to the support (protein-support interaction) which protects it from unfolding. The position of the lipase inside the pores of the support is also a key factor which ensures its stability against thermal denaturation $[63,64]$.

Similar optimum temperatures $\left(40^{\circ} \mathrm{C}\right)$ for both free and immobilized CRL suggested that the enzymatic properties of lipases were still maintained even after its immobilization onto organo-modified clay. However, thermal stability decreased after that as a result of the disturbance of the globular structure of the protein at high temperature. This causes unfolding of the enzyme tertiary structure which leads to loss in enzymatic activity [12]. The CRL-2.0 NK showed highest thermal stability due to the more rigid nature of the support even before organo-modification, where it contains kaolinite structure which is absent in MK. This has helped the enzyme immobilized onto it to remain stable even at higher temperatures [41,64].

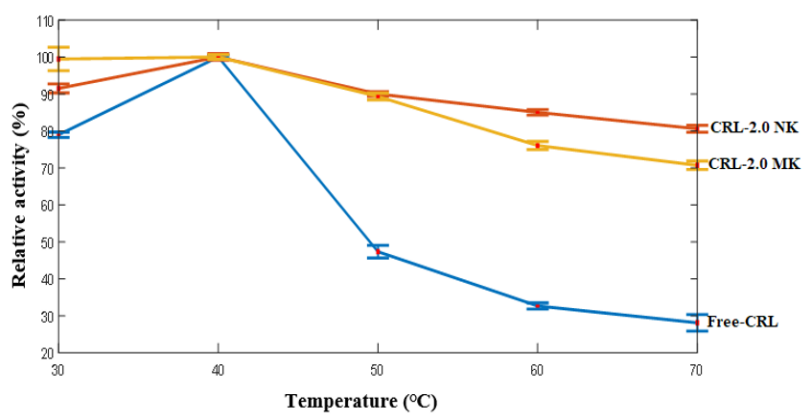

Figure 10. Thermal stability of free CRL and CRL immobilized onto organo-modified clays. 


\subsection{Reusability of Immobilized Lipases}

Enzyme reusability is a crucial parameter in the characterization of immobilized enzymes for practical applications. Enzymes in free form are excluded from the study of reusability because it is generally known that separation of free lipase from the reaction medium is almost impossible. Immobilized enzymes, on the other hand, are designed to meet the requirements of easy recovery and reusability to significantly reduce operational costs.

Figure 11 shows the reusability of immobilized CRL onto 2.0 NK and 2.0 MK in 10 consecutive reaction cycles. It can be seen that the relative activities of the immobilized lipases decreased gradually as the number of uses increased. This was due to the distortion of the enzyme active site as a result of recurrent instances with substrates which may have cause partial or total loss of catalytic efficiency. Likewise, active conformation of lipase may have been affected by excessive exposure to organic solvent. The loss in enzymatic activity could also be due to leaching effect which may have caused CRL to leach out from the pores of the supports [65].

After 10 continuous recycling, CRL-2.0 MK was found to maintain $62.56 \%$ of the initial activity, while CRL-2.0 NK maintained 38.53\% of its initial activity. In comparison to other immobilized enzyme on clay support materials, the operational stability (reusability) of the immobilized lipases in this study were comparably high. Edama et al. [66] reported that the reusability of enzyme immobilized onto waste clay recovered from palm oil mill effluent was only $32 \%$ after seven cycles of continuous uses. In this regard, the organoclay used in this present study was more effective in maintaining enzyme reusability due to the hydrophobic interfacial activation and stabilization of enzyme

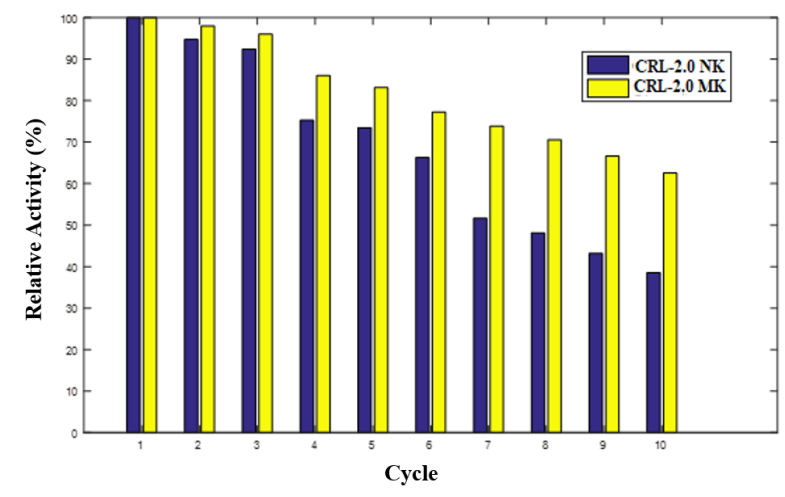

Figure 11. Percent relative activities showing reusability of CRL immobilized on $2.0 \mathrm{NK}$ and 2.0 MK. together with the presence of hydrogen bonds for better enzyme-support interactions. This helps to increase reusability of the immobilized lipases [66].

The hydrophobic surface of the organomodified clay may also help to prevent leaching of lipase protein into reaction medium, resulting in improved enzyme reusability [61]. The differences in reusabilities of the enzymes could also be related to the loading capacities of the supports. The 2.0 MK possesses larger pore size than the $2.0 \mathrm{NK}$, which is why better endurance can be observed when CRL-2.0 MK was in continuous use. This is in agreement with the findings by most researchers, that support materials with larger pore sizes are usually better carriers in promoting better enzyme reusabilities $[18,67,68]$. This clearly suggests that organo-modified metakaolin was able to better entrap lipase and retain its catalytic activity even after several uses, as compared to organo-modified kaolin.

\section{Conclusions}

An environmentally friendly, inexpensive and simple method to immobilize C. rugosa lipase (CRL) onto organo-modified kaolin and metakaolin have been studied. The results showed that the CRL immobilized on organomodified kaolin and metakaolin were able to act as biocatalysts to speed up the esterification reaction between nonanol and hexanoic acid. Comparison between the activities and stabilites of the free and immobilized CRL showed that immobilized CRL were thermally stable. CRL immobilized onto 2.0 MK also showed acceptably high reusability even after 10 cycles of repeated uses. These findings together with the advantages owned by the kaolin clay can be a new frontier for a wider application of organomodified kaolin clay for enzyme immobilization to be used in organic synthesis.

\section{Acknowledgment}

The authors would like to express their gratitude to the Faculty of Sciences and Technology, Universiti Sains Islam Malaysia (USIM) for the funding, technical support, and facilities provided. Authors would also like to thank the Libyan Ministry of Education for the financial support under the Postgraduate Scholarship Program. 


\section{References}

[1] Yeşiloğlu, Y. (2005). Utilization of bentonite as a support material for immobilization of Candida rugosa lipase. Process Biochemistry, $40, \quad 21555-2159$. $\quad$ D O I : 10.1016/j.procbio.2004.08.008.

[2] Othman, S.S., Basri, M., Hussein, M.Z., Rahman, M.B.A., Rahman, R.N.Z.A., Salleh, A.B., Jasmani, H. (2008). Production of highly enantioselective(-)-menthyl butyrate using Candida rugosa lipase immobilized on epoxyactivated supports. Food Chemistry, 106,

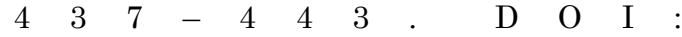
10.1016/j.foodchem.2007.04.026

[3] Sri Kaja, B., Lumor, S., Besong, S., Taylor, B., Ozbay, G. (2018). Investigating enzyme activity of immobilized Candida rugosa lipase. Journal of Food Quality, 2018, 1618085. DOI: $10.1155 / 2018 / 1618085$

[4] Srilatha, K., Lingaiah, N., Devi, B.P., Prasad, R.B.N., Venkateswar, S., Prasad, P.S. (2009). Esterification of free fatty acids for biodiesel production over heteropoly tungstate supported on niobia catalysts. Applied Catalysis A: General, $\quad 365, \quad 28-33$. D O I : 10.1016/j.apcata.2009.05.025.

[5] Marzuki, N.H.C., Huyop, F., Aboul-Enein, H.Y., Mahat, N.A., Wahab, R.A. (2015). Modelling and optimization of Candida rugosa nanobioconjugates catalysed synthesis of methyl oleate by response surface methodology. Biotechnology and Biotechnological Equipment, 29, 1113-1127. D I : 10.1080/13102818.2015.1078744.

[6] Musa, N., Latip, W., Abd Rahman, R.N.Z.A., Salleh, A.B., Mohamad Ali, M.S. (2018). Immobilization of an Antarctic Pseudomonas AMS8 lipase for low temperature ethyl hexanoate synthesis. Catalysts, 8, 234. DOI: 10.3390/catal8060234

[7] Dayi, B., Kyzy, A.D., Abduloglu, Y., Cikrikci, K., Akdogan, H.A. (2018). Investigation of the ability of immobilized cells to different carriers in removal of selected dye and characterization of environmentally friendly laccase of Morchella esculenta. Dyes and Pigments, 151, 15-21. DOI: 10.1016/j.dyepig.2017.12.038.

[8] Sheldon, R.A. (2007). Enzyme immobilization: the quest for optimum performance. Advanced Synthesis and Catalysis, 349, 12891307. DOI: $10.1002 /$ adsc. 200700082

[9] Homaei, A.A., Sariri, R., Vianello, F., Stevanato, R. (2013). Enzyme immobilization: An update. Journal of Chemical Biology, 6, 185205. DOI: $10.1007 / \mathrm{s} 12154-013-0102-9$

[10] Eş, I., Vieira, J.D.G., Amaral, A.C. (2015). Principles, techniques, and applications of biocatalyst immobilization for industrial appli- cation. Applied Microbiology and Biotechnology, 99, 2065-2082. DOI: 10.1007/s00253-0156390-y.

[11] Torres-Salas, P., del Monte-Martinez, A., Cutiño-Avila, B., Rodriguez-Colinas, B., Alcalde, M., Ballesteros, A.O., Plou, F.J. (2011). Immobilized biocatalysts: Novel approaches and tools for binding enzymes to supports. Advanced Materials, 23, 5275-5282. DOI: 10.1002/adma.201101821

[12] Abdul Rahman, M.B.A., Yunus, N.M.M., Hussein, M.Z., Rahman, R.N.Z.A., Salleh, A.B., Basri, M. (2005). Application of advanced materials as support for immobilisation of lipase from Candida rugosa. Biocatalysis and Biotransformation, 23, 233-239. DOI: $10.1080 / 10242420500218703$.

[13] Šnekuljica, N.Ž., Prlainović, N.Ž., Jovanović, J.R., Stefanović, A.B., Grbavčić, S.Ž., Mijin, D.Ž., Knežević-Jugović, Z.D. (2016). Immobilization of horseradish peroxidase onto kaolin by glutaraldehyde method and its application in decolorization of anthraquinone dye. Hemijska Industrija, 70, 217-224. DOI: 10.2298/HEMIND150220028S.

[14] Mulinari, J., Oliveira, J.V., Hotza, D. (2020). Lipase immobilization on ceramic supports: An overview on techniques and materials. $B i$ otechnology Advances, 42, 107581. DOI: 10.1016/j.biotechadv.2020.107581.

[15] Winayanuwattikun, P., Kaewpiboon, C., Piriyakananon, K., Chulalaksananukul, W., Yongvanich, T., Svasti, J. (2011). Immobilized lipase from potential lipolytic microbes for catalyzing biodiesel production using palm oil as feedstock. African Journal of Biotechnology, 10, 1666-1673. DOI: 10.5897/AJB10.1802.

[16] Liu, Y., Zhou, H., Wang, L., Wang, S. (2016). Stability and catalytic properties of lipase immobilized on chitosan encapsulated magnetic nanoparticles cross-linked with genipin and glutaraldehyde. Journal of Chemical Technology and Biotechnology, 91, 1359-1367. DOI: 10.1002/jctb.4732.

[17] Benamia, F., Benouis, S., Belafriekh, A., Semache, N., Rebbani, N., Djeghaba, Z. (2017). Efficient Candida rugosa lipase immobilization on Maghnite clay and application for the production of (1R)-(-)-Menthyl acetate. Chemical Papers, 71, 785-793. DOI: 10.1007/s11696-016-0080-9.

[18] Jafarian, F., Bordbar, A.K., Zare, A., Khosropour, A. (2018). The performance of immobilized Candida rugosa lipase on various surface modified graphene oxide nanosheets. International Journal of Biological Macromolecules, 111, 1166-1174. DOI: 10.1016/j.ijbiomac.2018.01.133. 
[19] Tanasković, S.J., Jokić, B., Grbavčić, S., Drvenica, I., Prlainović, N., Luković, N., Knežević-Jugović, Z. (2017). Immobilization of Candida antarctica lipase B on kaolin and its application in synthesis of lipophilic antioxidants. Applied Clay Science, 135, 103-111. DOI: 10.1016/j.clay.2016.09.011.

[20] de Souza Lima, J., Costa, F.N., Bastistella, M.A., de Araújo, P.H.H., de Oliveira, D. (2019). Functionalized kaolin as support for endoglucanase immobilization. Bioprocess and Biosystems Engineering, 42, 1165-1173. DOI: $10.1007 / \mathrm{s} 00449-019-02113-\mathrm{w}$.

[21] Scherer, R., Oliveira, J.V., Pergher, S., Oliveira, D.D. (2011). Screening of supports for immobilization of commercial porcine pancreatic lipase. Materials Research, 14, 483492 . D O I : $10.1590 / \mathrm{S} 1516$ 14392011005000079 .

[22] Shindo, H., Watanabe, D., Onaga, T., Urakawa, M., Nakahara, O., Huang, Q. (2002). Adsorption, activity, and kinetics of acid phosphatase as influenced by selected oxides and clay minerals. Soil Science and Plant Nutrition, $48, \quad 763-767$. D O I : 10.1080/00380768.2002.10409268

[23] Huang, Q., Liang, W., Cai, P. (2005). Adsorption, desorption and activities of acid phosphatase on various colloidal particles from an Ultisol. Colloids and Surfaces B: Biointerfaces $, \quad 45, \quad 209-214$. D O I : 10.1016/j.colsurfb.2005.08.011

[24] Salehi, M., Salem, A. (2008). Effect of moisture content on extrusion process of kaolinitic-illitic clay in manufacturing of ceramic Raschig ring. Journal of Materials Processing Technology, 200, 232-237. DOI: 10.1016/j.jmatprotec.2007.09.013

[25] Ajayi, O.A., Nok, A.J., Adefila, S.S. (2012). Immobilization of cassava linamarase on Kankara kaolinite clay. Journal of Natural Sciences Research, 2, 55-62.

[26] Dong, H., Li, Y., Sheng, G., Hu, L. (2013). The study on effective immobilization of lipase on functionalized bentonites and their properties. Journal of Molecular Catalysis B: Enzymatic, $95, \quad 9-15$. D O I : 10.1016/j.molcatb.2013.05.018

[27] Frías, M., García, R., Vigil, R., Ferreiro, S. (2008). Calcination of art paper sludge waste for the use as a supplementary cementing material. Applied Clay Science, 42, 189-193. DOI: 10.1016/j.clay.2008.01.013.

[28] Arctander, S. (2019) Perfume \& Flavor Chemicals (Aroma Chemicals). Vol. II (Vol. 2). Lulu.com.
[29] Tosun, A., Kürkçüoglu, M., Başer, K.H.C. (2006). Essential Oils of Tordylium pestalozzae Boiss, Tordylium pustulosum Boiss. and Tordylium lanatum (Boiss.) Boiss. (Umbelliferae) Growing Wild in Turkey. Journal of Essential Oil Research, 18(6), 640 642. DOI: 10.1080/10412905.2006.9699191.

[30] Santamarina, J.C., Klein, K.A., Wang, Y.H., Prencke, E. (2002). Specific Surface: Determination and Relevance. Canadian Geotechnical Journal, 39, 233-241. DOI: 10.1139/T01-077.

[31] Bradford, M.M. (1976). A rapid and sensitive method for the quantitation of microgram quantities of protein utilizing the principle of protein-dye binding. Analytical Biochemistry, 72, 248-254. DOI: 10.1016/00032697(76)90527-3.

[32] Ramli, M.B., Alonge, O.R. (2016). Characterization of metakaolin and study on early age mechanical strength of hybrid cementitious composites. Construction and Building Materials, $\quad 121, \quad 599-611$. D O I : 10.1016/j.conbuildmat.2016.06.039

[33] Rashad, A.M. (2013). Metakaolin as cementitious material: History, scours, production and composition-A comprehensive overview. Construction and Building Materials, 41, $\begin{array}{llllllllllll} & 3 & 0 & 3 & - & 3 & 1 & 8 & . & \mathrm{D} & \mathrm{O} & \mathrm{I}\end{array}$ 10.1016/j.conbuildmat.2012.12.001

[34] Mgbemena, C.O., Ibekwe, N.O., Mohamed, A.A.P., Sukumar, R., Menon, A.R.R. (2013). Thermal behavior and UV properties of organomodified kaolin oleochemically derived from rubber seed oils (Hevea brasiliensis) and tea seed oils (Camellia sinensis). Journal of Surface Engineered Materials and Advanced Technology, 3, 163-168. DOI: 10.4236/jsemat.2013.33021.

[35] Adamis, Z., Williams, R.B., Fodor, J. (2005). Bentonite, kaolin, and selected clay minerals. (No. 231). World Health Organization.

[36] Konan, K.L., Peyratout, C., Bonnet, J.P., Smith, A., Jacquet, A., Magnoux, P., Ayrault, P. (2007). Surface properties of kaolin and illite suspensions in concentrated calcium hydroxide medium. Journal of Colloid and Interface Science, 307, 101-108. DOI: 10.1016/j.jcis.2006.10.085

[37] Konan, K.L., Peyratout, C., Smith, A., Bonnet, J.P., Rossignol, S., Oyetola, S. (2009). Comparison of surface properties between kaolin and metakaolin in concentrated lime solutions. Journal of Colloid and Interface Science, $\quad 339, \quad 103-109$. D O I : 10.1016/j.jcis.2009.07.019 
[38] Boukhemkhem, A., Rida, K. (2017). Improvement adsorption capacity of methylene blue onto modified Tamazert kaolin. Adsorption Science and Technology, 35, 753-773. DOI: 10.1177/0263617416684835

[39] Liew, Y.M., Kamarudin, H., Al Bakri, A.M., Luqman, M., Nizar, I.K., Ruzaidi, C.M., Heah, C.Y. (2012). Processing and characterization of calcined kaolin cement powder. Construction and Building Materials, 30, 794-802. DOI: 10.1016/j.conbuildmat.2011.12.079

[40] Jahan, S.A., Parveen, S., Ahmed, S., Kabir, H. (2012). Development and characterization of organophilic clay from bentonite. Materials Science: An Indian Journal, 8, 67-72.

[41] Ramos, M.D., Gómez, G.I.G., González, N.S. (2014). Immobilization of Candida rugosa lipase on bentonite modified with benzyltriethylammonium chloride. Journal of Molecular Catalysis B: Enzymatic, 99, 79-84. DOI: 10.1016/j.molcatb.2013.10.021

[42] Lambert, J.F., Millman, W.S., Fripiat, J.J. (1989). Revisiting kaolinite dehydroxylation: A silicon-29 and aluminum-27 MAS NMR study. Journal of the American Chemical Society, $111, \quad 3517-3522$. D O I : 10.1021/ja00192a005.

[43] Duarte-Silva, R., Villa-García, M.A., Rendueles, M., Díaz, M. (2014). Structural, textural and protein adsorption properties of kaolinite and surface modified kaolinite adsorbents. Applied Clay Science, 90, 73-80. DOI: 10.1016/j.clay.2013.12.027.

[44] Zhang, S., Deng, Q., Li, Y., Zheng, M., Wan, C., Zheng, C., Tang, H., Huang, F., Shi Shi, J. (2018). Novel amphiphilic polyvinylpyrrolidone functionalized silicone particles as carrier for low-cost lipase immobilization. Royal Society Open Science, 5, 172368. DOI: 10.1098/rsos.172368.

[45] Kakali, G., Perraki, T.H., Tsivilis, S., Badogiannis, E. (2001). Thermal treatment of kaolin: The effect of mineralogy on the pozzolanic activity. Applied Clay Science, 20, 73-80. DOI: 10.1016/S0169-1317(01)00040-0.

[46] Zhang, X., Liu, H., Xing, H., Li, H., Hu, H., Li, A., Yao, H. (2017). Improved sodium adsorption by modified kaolinite at high temperature using intercalation-exfoliation method. Fuel, $191, \quad 198-203$. D O I : 10.1016/j.fuel.2016.11.067.

[47] Meziane, O., Bensedira, A., Guessoum, M., Haddaoui, N. (2017). Preparation and characterization of intercalated kaolinite with: Uurea, dimethyl formamide and an alkylammonium salt using guest displacement reaction. Journal of Materials, 8, 3625-3635.
[48] Mota, M.F., Patrício, A.C.L., da Silva, M.M., Freire Rodrigues, M.G. (2015). Preparation and characterization of clay chocolate "A" organoclay using stearyldimethyl ammonium chloride as a surfactant. Materials Science Forum, 805, 667-671. DOI: 10.4028/www.scientific.net/MSF.805.667.

[49] Monteiro Jr, O.A., Airoldi, C. (1999). Some studies of crosslinking chitosanglutaraldehyde interaction in a homogeneous system. International Journal of Biological Macromolecules, 26, 119-128. DOI: 10.1016/S0141-8130(99)00068-9

[50] Airoldi, C., Monteiro Jr, O.A. (2000). Chitosan-organosilane hybrids-Syntheses, characterization, copper adsorption, and enzyme immobilization. Journal of Applied Polymer Science, 77, 797-804. DOI: $10.10002 /$ ( S I C I ) 100967 . $4628(20000725) 77: 4<797:$ : A ID APP12>3.0.CO;2-Z

[51] Gopinath, S., Sugunan, S. (2007). Enzymes immobilized on montmorillonite K 10: effect of adsorption and grafting on the surface properties and the enzyme activity. Applied Clay Science, 35, 67-75. DOI: 10.1016/j.clay.2006.04.007.

[52] Rostami, E., Norouzbeigi, R., Rahbar, A. (2018). Thermal and chemical modification of bentonite for adsorption of an anionic dye. Advances in Environmental Technology, 4, 112. DOI: 10.22104/AET.2018.1844.1088.

[53] Parolo, M.E., Pettinari, G.R., Musso, T.B., Sánchez-Izquierdo, M.P., Fernández, L.G. (2014). Characterization of organo-modified bentonite sorbents: The effect of modification conditions on adsorption performance. $A p$ plied Surface Science, 320, 356-363. DOI: 10.1016/j.apsusc.2014.09.105.

[54] Díaz, M., Villa-García, M.A., Duarte-Silva, R., Rendueles, M. (2017). Preparation of organomodified kaolinite sorbents: The effect of surface functionalization on protein adsorption performance. Colloids and Surfaces A: Physicochemical and Engineering Aspects, 530, 181-190. DOI: 10.1016/j.colsurfa.2017.07.067.

[55] Zaidan, U.H., Rahman, M.BA., Basri, M., Othman, S.S., Rahman, R.N.Z.R.A., Salleh, A.B. (2010). Silylation of mica for lipase immobilization as biocatalysts in esterification. Applied Clay Science, 47(3-4), 276-282. DOI: 10.1016/j.clay.2009.11.004

[56] Golbaha, N., Ramli, Z., Endud, S. (2016). Immobilization of lipase onto mesoporous silica KIT-6 and montmorillonite K10 for enzymatic hydrolysis of tributyrin. Malaysian Journal of Fundamental and Applied Sciences, 12, 3946. DOI: $10.11113 /$ mjfas.v12n1.419. 
[57] Sanjay, G., Sugunan, S. (2006). Enhanced pH and thermal stabilities of invertase immobilized on montmorillonite K-10. Food Chemis$t r y, \quad 94, \quad 573-579$. D O I : 10.1016/j.foodchem.2004.12.043.

[58] Puranik, R.V., Kumar, P., Bhat, Y.S., Prakash, B.J. (2010). A perspective of the interlamellar region of organo-clays by adsorption of aromatic hydrocarbons. Journal of Porous Materials, 17, 485-490. DOI: 10.1007/s10934009-9311-6.

[59] Elgubbi, H. M., Othman, S. S., Harun, F. W. (2020). Modification of kaolinite clay using benzyltriethylammonium chloride as a surfactant: Preparation and characterization. International Journal of Engineering and Technology, $9(4), \quad 850-856$. D O I : 10.14419/ijet.v9i4.31088

[60] Romero, C.M., Spuches, F.C., Morales, A.H., Perotti, N.I., Navarro, M.C., Gómez, M.I. (2018). Design and characterization of immobilized biocatalyst with lipase activity onto magnetic magnesium spinel nanoparticles: A novel platform for biocatalysis. Colloids and Surfaces B: Biointerfaces, 172, 699-707. DOI: 10.1016/j.colsurfb.2018.08.071.

[61] Öztürk, H., Pollet, E., Phalip, V., Güvenilir, Y., Avérous, L. (2016). Nanoclays for lipase immobilization: Biocatalyst characterization and activity in polyester synthesis. Polymers, 8, 416. DOI: $10.3390 /$ polym8120416.

[62] Paul, C., Borza, P., Marcu, A., Rusu, G., Bîrdeanu, M., Zarcula, S.M., Péter, F. (2016). Influence of the physico-chemical characteristics of the hybrid matrix on the catalytic properties of sol-gel entrapped Pseudomonas fluorescens lipase. Nanomaterials and Nanotechnology, 6, 3. DOI: 10.5772/62194.

[63] Miranda, M., Urioste, D., Andrade Souza, L.T., Mendes, A.A., de Castro, H.F. (2011). Assessment of the morphological, biochemical, and kinetic properties for Candida rugosa lipase immobilized on hydrous niobium oxide to be used in the biodiesel synthesis. Enzyme Research, 2011, 216435. DOI: $10.4061 / 2011 / 216435$.
[64] Kharrat, N., Ali, Y.B., Marzouk, S., Gargouri, Y.T., Karra-Châabouni, M. (2011). Immobilization of Rhizopus oryzae lipase on silica aerogels by adsorption: Comparison with the free enzyme. Process Biochemistry, 46, 1083-1089. DOI: $10.1016 /$ j.procbio.2011.01.029.

[65] Patel, V., Gajera, H., Gupta, A., Manocha, L., Madamwar, D. (2015). Synthesis of ethyl caprylate in organic media using Candida rugosa lipase immobilized on exfoliated graphene oxide: Process parameters and reusability studies. Biochemical Engineering Journal, 95, 62-70. DOI: 10.1016/j.bej.2014.12.007

[66] Edama, N.A., Sulaiman, A., Abd-Rahim, S.N., Hamid, K.H.K., Busu, Z. (2014). Characterization of waste clay from palm oil mill effluent and enzyme immobilization study for cassava saccharification process. BioResources, 9, 7278-7287. DOI: 10.15376/biores.9.4.72787287.

[67] Handayani, N., Miletic, N., Loos, K., Achmad, S., Wahyuningrum, D. (2011). Properties of immobilized Candida antarctica lipase B on highly macroporous copolymer. Sains Malaysiana, 40, 965-972.

[68] Zhang, S., Shi, J., Deng, Q., Zheng, M., Wan, C., Zheng, C., Li, F., Huang, F. (2017). Preparation of carriers based on $\mathrm{ZnO}$ nanoparticles decorated on graphene oxide (GO) nanosheets for efficient immobilization of lipase from Candida rugosa. Molecules, 22, 1205. DOI: 10.3390/molecules22071205. 